\title{
18. POLLEN OCCURRENCE IN EASTERN NORTH PACIFIC SEDIMENTS, DEEP SEA DRILLING PROJECT LEG 18
}

\author{
Lillian F. Musich, Deep Sea Drilling Project, Scripps Institution of Oceanography, La Jolla, California
}

\section{INTRODUCTION}

Land floras are extremely sensitive to climatic changes and are distinctive indicators of continental temperature and moisture conditions. It is probable that plants living today occupied, in Neogene and Quaternary time (Leopold, 1969), the same type of habitat in which they are now found.

Pollen and spores show no sign of having evolved during the last $2 \mathrm{~m} . \mathrm{y}$., have extremely resistant outer coatings or exines which make them resistant to destruction, and are almost ubiquitous in continental and near-shore sediments. These factors make pollen important in deducing Pleistocene climates from ocean sediments as well as from land deposits.

Until now, no pollen criteria have been established for recognizing glacial-interglacial boundaries in oceanic sediments of the northeast Pacific region. With cores from the Deep Sea Drilling Project Sites 173, 174, and 175 (the Delgada and Astoria deep sea fans), the author will attempt to determine some of these criteria. The reasons for studying pollen of this particular area were: (a) a long and probably uninterrupted sequence of terrigenous Pleistocene sediments has been recovered from DSDP Sites 173, 174, 175; (b) the pollen sequence of the adjacent land section is known; (c) there is enough supportive evidence from marine microfossils in the sediments to establish relative geologic ages (Figures 1 and 2).

The goals of this study were to (a) determine climatologically significant pollen criteria for the Pleistocene of the North Pacific and use these criteria to determine Pleistocene climatic changes, and (b) correlate pollen stratigraphy with that of cooccurring marine microfossils.

\section{METHODS}

\section{Sample Preparation}

The average sample size was 5 grams. Samples were treated with a 10 percent potassium hydroxide solution to remove organic colloids and 25 percent $\mathrm{HC} 1$ to remove calcium carbonate. The pollen was then separated by heavy liquid flotation (zinc chloride solution, specific gravity 2.0 ) as described by Brown (unpublished manuscript, 1960). Although determination of absolute pollen frequencies is precluded by this method, it was possible to determine relative pollen abundances.

After processing, residues were stained with Safranin " 0 " and mounted in glycerine jelly. A minimum count of 200 grains per sample was attempted; however, this was not always possible owing to some extremely low pollen frequencies. Where fifty grains or less were counted, the data are noted in Tables 1 through 3, but not used in construction of the final pollen diagrams (Figures 3-5).
Specimens observed were identified to the genus level. Generic determinations were based on Erdtman (1943). Dinoflagellates are absent or very rare in samples observed. Their presence is noted on Tables 4 to 6 , but no attempt was made to identify them.

The abundance of palynomorphs was determined by counting the number of grains appearing under a single, standard $22 \times 30 \mathrm{~mm}$ glass cover slip. The following scale was used:

$\begin{array}{ll}\text { Abundant } & 150+\text { grains per slide } \\ \text { Common } & 75-150 \\ \text { Few } & 30-75 \\ \text { Rare } & \text { less then } 30\end{array}$

This nomenclature is used in Tables 4 to 6 for comparison with other microfossils at the sites studied.

Only species which occur repeatedly in quantities greater than 2 percent were plotted on the pollen diagrams. Occasional occurrences of Ulmus and Castanopsis, as well as reworked Ephedra and Ginkgo (mostly from the Miocene of Site 173), were noted on Tables 1 through 3 but were not plotted.

\section{Preservation}

Three major categories of preservation were observed in the samples studied and are illustrated on Plate 1, Figure 1. The first category consists of grains that stain pale pink in Safranin "0", are intact, and have uncorroded emphytipic and haptotypic structures (Plate 1, Figure 1A). The second category consists of grains that have been corroded; i.e., surface ornamentation appears abraded and grains may be fragmented (Plate 1, Figure 1B). The third category consists of grains that may or may not be mechanically abraded, but show definite signs of oxidation and carbonization (Plate 1, Figure 1C). The grains of the last category always stain deep yellow or brownish yellow in Safranin "0". It is possible that both the second and third categories are reworked; however, it is also possible that the third preservation category is a result of diagenetic alteration caused by increased temperature and pressure (Staplin, 1969). It is this type of poor preservation that becomes prevalent at the bottom of Holes 173, 174, and 174A, and at the Gulf of Alaska sites.

\section{Paleoecological Criteria}

In attempting to determine criteria applicable in establishing climatic boundaries, three parameters were used and compared.

1. Occurrence of climatically important species in the area.

The Pleistocene and post-Pleistocene palynology of the land section in southern Oregon is found in studies by Hansen (1938, 1941, 1945, 1947; Hansen and Allison, 1942 - see Figure 2 for location of Hansen's sites) of 


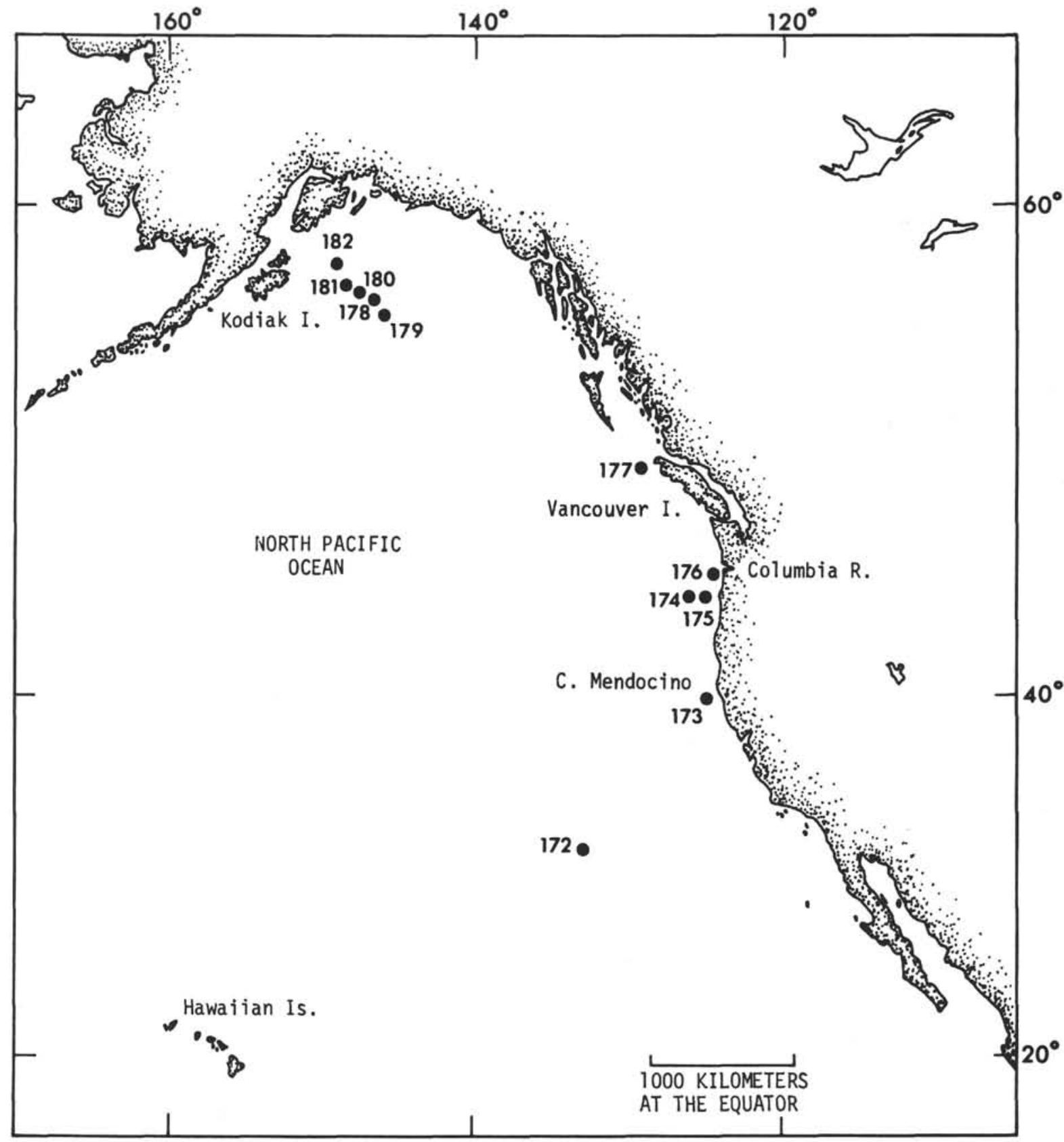

Figure 1. Location of sites, DSDP Leg 18.

coastal bogs of the region. He deals with the occurrence and cooccurrence of three dominating species: lodgepole pine, Sitka spruce, western hemlock. The primary pioneers and most tolerant species of the coastal north Pacific area is Pinus contorta. It is able to survive on the sandy, nonvegetated, unstable coastal soil and can tolerate direct sunlight. After pine has created a suitable environment, the next species to invade the area is Picea. Eventually Picea, in general, trees larger than the pine, will crowd out the pine. The proportion of Pinus to Picea is important in determining how stable the soil and how moderate the climate. When the climate is sufficiently ammeliorated and the soil fairly stable, Tsuga will appear (Hansen, 1941; Hansen and Allison,
1942). These three conifers are dominant at all sites studied in detail. The fluctuations observed in coastal land sections compare well with those of the marine sections.

2. Biotic Diversity.

According to Fischer (1960), "The diversity of biotas on land and in the sea is greatest in climates of relatively high and constant temperatures, such as those found over much of the tropics, and decreases progressively into the fluctuating and the cold climates associated with higher latitudes."

As continental glaciers increase in size, the snow line is lowered and hence a shift in climatic zones occurs, with changes in temperature, rainfall frequency, and seasonabil- 


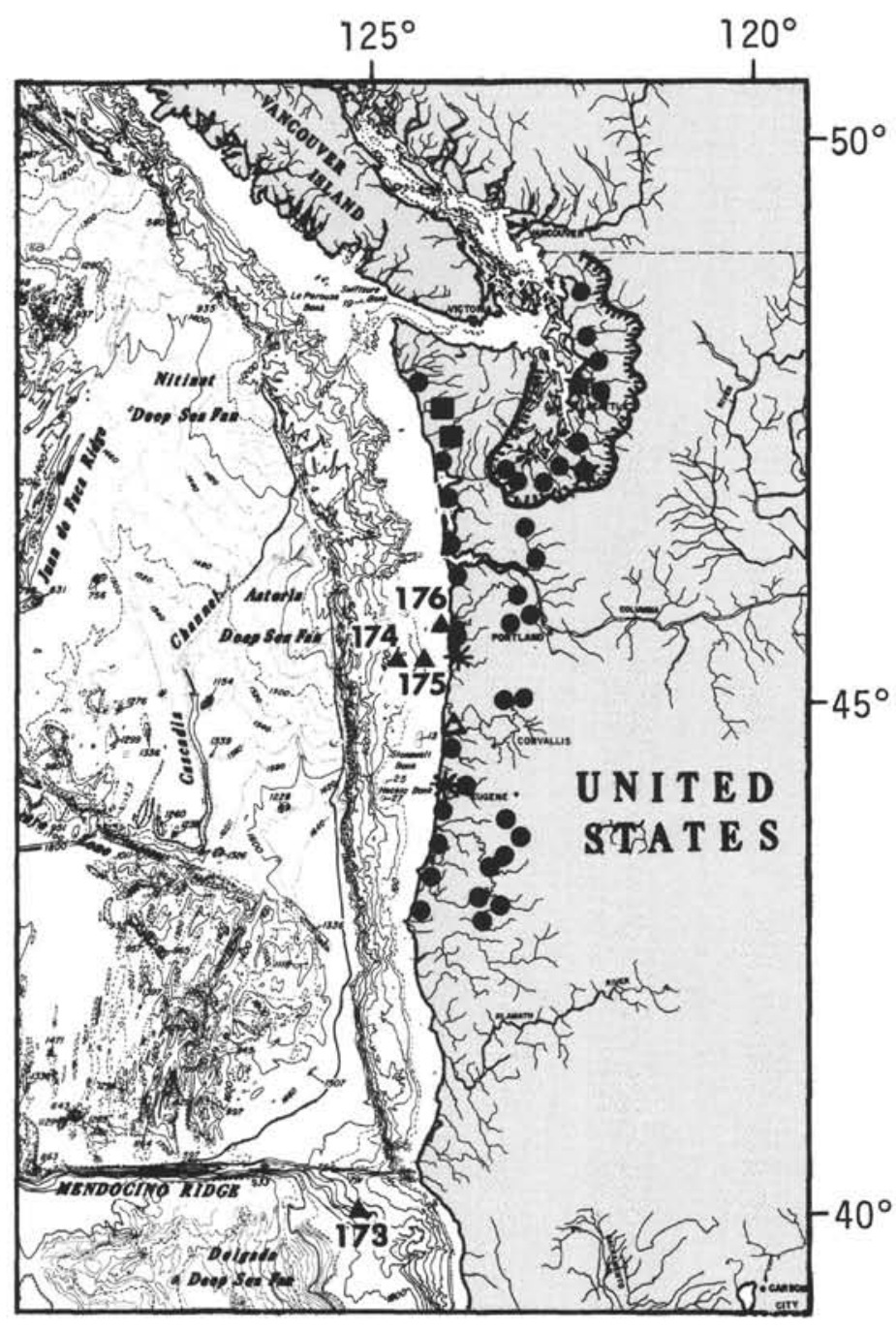

$\triangle$ HANSEN AND ALLISON, 1942 - PLEIST. * HANSEN, 1941C - PLEIST.

HEUSSER, 1964 - PLEIST. $\star$ HANSEN, 1938 - PLEIST.

- HANSEN, 1947 - PLEIST. (PARTIAL LIST) I SOUTHERNMOST GLACIAL EXTENSION

Figure 2. Topographic map of the northeast Pacific and adjacent land area showing location of Sites 173, 174, 175 , and 176, location of related land studies, and southernmost extension of Wisconsin glaciation (hatched line).

ity. Because a land flora is obviously unable to move to a more suitable locality when changes occur, its biotic diversity is directly affected by changes in climate which occur even over a short period of time. Usually, the amount of time involved in these climatic changes is so short that the changes cannot be attributed to evolution or change in ecologic tolerance of a particular genus. Hence, it is possible to apply genetic diversity as an aid to interpretation of glacial-interglacial chronology.

Norem (1956) observed sharp changes in the diversity of pollen genera in samples from the Bakersfield, California, area. These breaks occur in the lower and upper Miocene and middle Pliocene. Sudden decreases were attributed to a drastic climatic change, such as a shift from summer to winter rainfall. The change in diversity in the north Pacific coastal sites is probably due to climatic change of a similar sort resulting from the proximity of a continental glacier (Figure 2).

In order to determine diversity trends, the following statistical formula was used and results plotted on the pollen diagram:

$$
\text { Diversity }=\frac{N(N-1)}{\sum_{i=1}^{k} n_{i}\left(n_{i}-1\right)}
$$

where:

$$
\begin{aligned}
& \mathrm{N}=\text { total specimens } \\
& \mathrm{n}_{\mathrm{i}}=\text { no. of specimens of the ith species } \\
& \mathrm{k}=\text { total no. of species }
\end{aligned}
$$

At Site 173, a sharp rise in the trend of diversity occurs at 75 meters, which corresponds to the Plio-Pleistocene boundary as determined by marine microfossils. This highdiversity trend coordinates well with a sudden drop in pine frequency and also with a warming trend indicated by diatom populations.

Site 174 diversity shows a good inverse correlation with pine frequency. In almost every instance where the pine count drops, diversity increases.

3. Occurrence of reworked pollen grains.

Stanley (1965) suggested that, at times when ice caps are most extensive, the amount of reworked pollen (from lowered base level) should be greatest because, as continental glaciers increase in size, sea level falls, and hence more shoreline is exposed to erosion. Grains that are positively reworked are those that are either (a) recognized as being from a plant now extinct worldwide, or (b) recognized as being from a plant extinct only in the particular area under consideration.

The sudden increase in reworked pollen at the bottom of Hole 174 at 280 meters $(27, \mathrm{CC})$ corresponds to an unconformity on the seismic profile record and to a change in lithology from turbidite sands to fissile clay. This increase in occurrence of reworked specimens is more likely due to a change in sediment source, a change in locus of deposition, or an increase in temperature or pressure than to a glacioeustatic effect. von Huene and Kulm (Chapter 33, this volume) suggest that this change in deposition from clay to sand may indicate the onset of major glaciation in this area. If this is true, then reworked pollen in this particular site shows a trend opposite to that of Stanley's hypothesis.

The percentage of reworked grains remains fairly constant to 76 meters (in Hole 174), fluctuates sharply from 
TABLE 1

Palynomorph Occurrence, Site 173

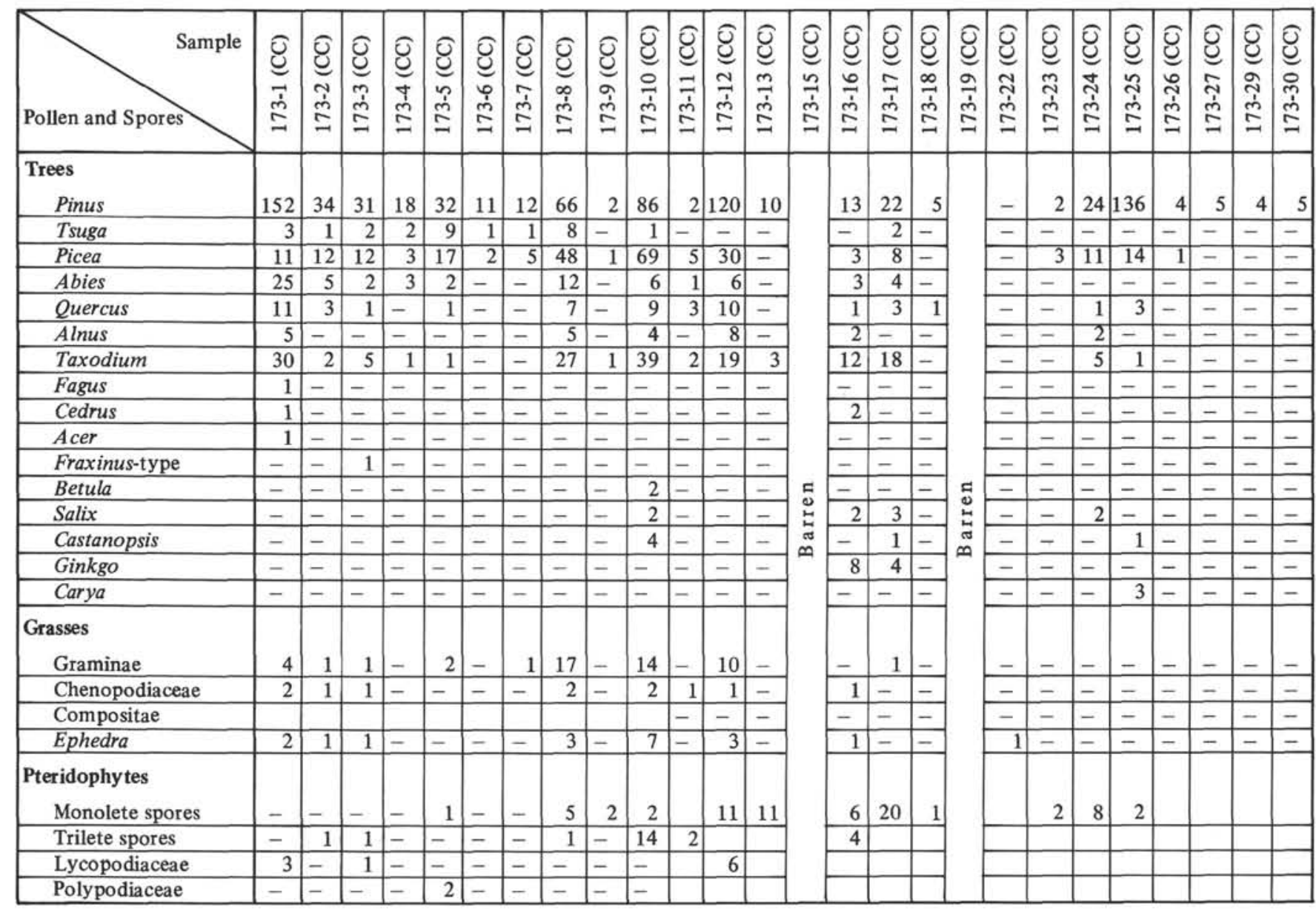

76 to 224 meters, becomes relatively constant from 224 to 288 meters, with a gradual increase below this point.

The tectonic activity and changes in geomorphology of the Oregon-northern California coast is also greater than that of the east coast of the U. S., and therefore exposure of shoreline may be due to other than eustatic causes. Hence, the occurrence of reworked palynomorphs to determine glacial boundaries is not reliable in this area.

\section{SITE SUMMARIES}

Fifteen holes at eleven sites were drilled during Leg 18 (Figure 1).

\section{Site $172\left(31^{\circ} 32^{\prime} \mathrm{N}, 133^{\circ} 22^{\prime} \mathrm{W}\right.$; water depth $\left.4767 \mathrm{~m}\right)$}

Palynomorphs were not found in the brown zeolitic clays of Site 172. The absence of pollen and spores in this sequence is probably due to distance of this site from a major land mass but may also be the result of postdepositional oxidation.

\section{Site $173\left(39^{\circ} 57^{\prime} \mathrm{N}, 125^{\circ} 27^{\prime} \mathrm{W}\right.$; water depth $\left.2927 \mathrm{~m}\right)$}

Site 173 is located approximately 50 miles off Cape Mendocino, California. The sediments down to 138 meters are predominantly terrigenous silty clays and fine sand (Core
16); diatomite with some nanno ooze to 285 meters (Cores 17-31); and mudstone, nannofossil ooze, and andesite basalt to 320 meters.

Palynomorphs are common to abundant in Cores 1 through $18(0-167 \mathrm{~m})$ and in Core $25(224-233.5 \mathrm{~m})$ but are virtually absent from all other samples examined. The absence of pollen in the majority of cores sampled is probably due to dilution of terrigenous material by marine microfossils, particularly diatoms (Korneva, 1964), and by the lack of preservation of pollen grains at the base of the hole. The latter phenomenon is reflected by the increasing percentage of poorly preserved pollen downhole, where in the case of Core 25 they form 90 percent of the sample. Corrosion and yellow staining of pollen may result from overburden pressure and high temperature (Staplin, 1969).

The composition of assemblages encountered indicates fluctuating cooler and warmer conditions on land, but most dramatic is the sharp break at the base of Core $8(72 \mathrm{~m})$ indicating a warm period which continues almost to the base of the section studied. Pine frequency decreases from a maximum of 85 percent at 55 meters to a minimum of 10 percent at 100 meters. Correspondingly, there is an increase in species diversity. This break corresponds to the PliocenePleistocene boundary as determined by marine microfossils. 


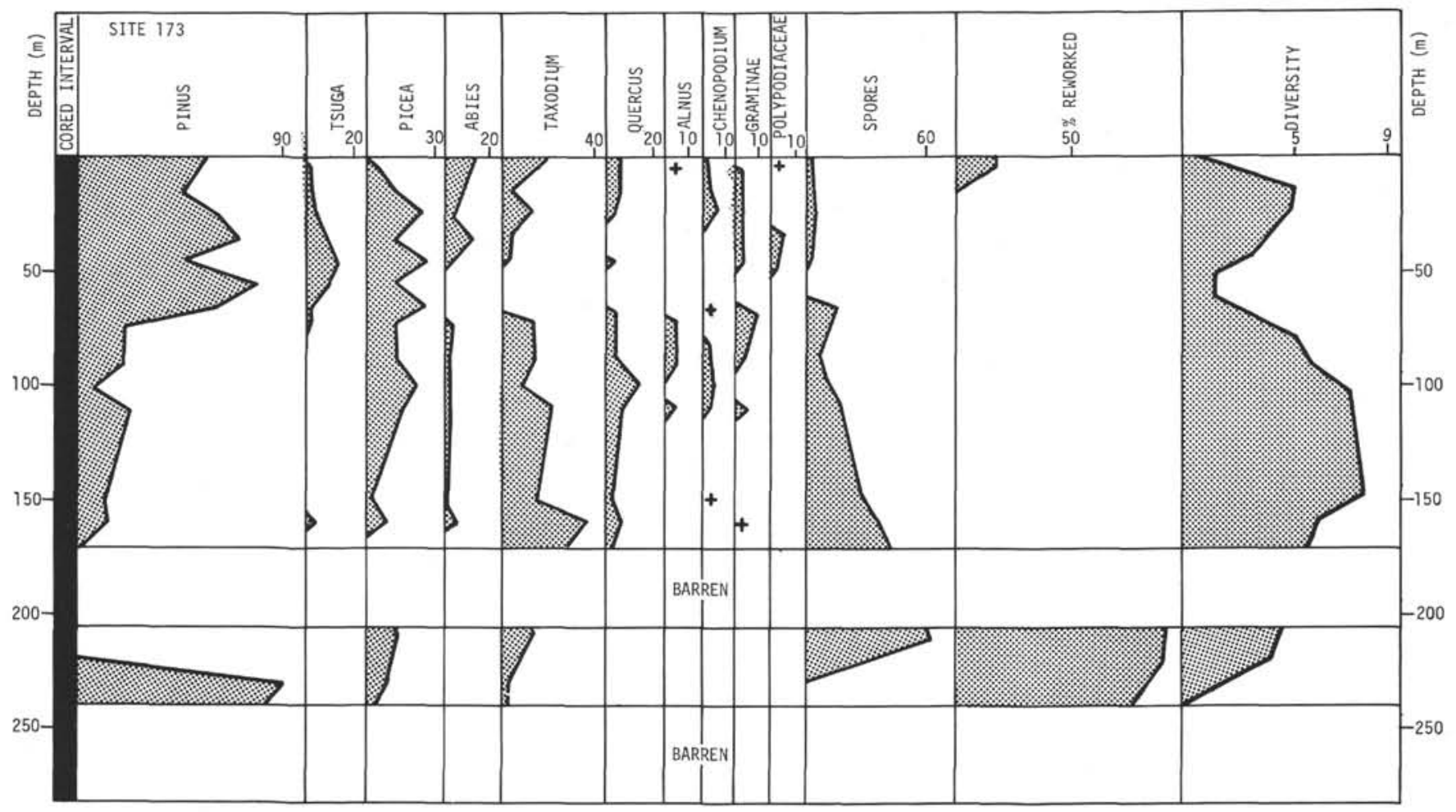

Figure 3. Pollen diagram, Site 173.

The lack of detail in climatic trends at Site 173 is probably the result of a relatively wide sample interval, precluding the detection of small-scale climatic events.

The appearance of Ephedra in Core $12(110 \mathrm{~m})$ marks the only occurrence at this site of a genus extinct in this area since Pliocene time.

Site $174\left(44^{\circ} 53^{\prime} \mathrm{N}, 126^{\circ} 21^{\prime} \mathrm{W}\right.$; water depth 2815 and 2799 m)

Site 174 , located approximately 300 miles northwest of Site 173 and about 75 miles from land, was drilled in the Astoria submarine fan, which is formed of sediment from the Columbia River. A late Pleistocene succession of medium to very fine turbidite sands grading into silt or silty clay was retrieved from the upper 284 meters of Hole 174A. From 284 to 879 meters the turbidite beds occur less frequently and finally grade to a gray fissile mud. The very thick and almost completely cored Pleistocene section of this site provided the most useful pollen data of the entire leg. The occurrence of palynomorphs varies from abundant to rare. Pollen frequency is highest in Cores 1 and 2 of Hole 174 and Cores 1, 5, 6, 7, 11 to $14,17,18,22,27,28,31$, and 33 of Hole 174A. Pollen frequency below Core 35 $(417 \mathrm{~m})$ is so low that statistically reliable counts could not be made. The percentage of "reworked" grains increases dramatically below 280 meters, probably in conjunction with the lithologic change at 280 meters.

It is important to note that turbidite deposition may play an important role in masking and diluting palynomorphs at this site. Rapid deposition of sediments may explain the frequent and sudden disappearance of all palynomorphs and the common occurrence of reworked material.
Indications of warm conditions on the adjacent land mass, consisting of a mature conifer forest where Tsuga frequency and genetic diversity are high and pine frequency is low, were found at 31.1 meters $(174-1-1,138-140)$, 94.5 meters $(174 \mathrm{~A}-7, \mathrm{CC})$, and 132.5 meters $(11, \mathrm{CC})$. The warming at 132.5 meters is the most striking, since at this point Tsuga constitutes almost 50 percent of the sample. Foraminifera and nannofossils at this level also indicate a warm condition.

\section{Site $175\left(44^{\circ} 50^{\prime} \mathrm{N}, 125^{\circ} 14^{\prime} \mathrm{W}\right.$; water depth $\left.1999 \mathrm{~m}\right)$}

Site 175 is located about 25 miles east of site 174 in a small synclinal trough on the lower continental slope off central Oregon. Sediment types are predominantly dark greenish gray mud with occasional thin beds of fine sand and coarse silt. Medium gray mud rich in detrital carbonate occurs as intercalations in the lower portion of the hole.

Cores 3,5 , and 8 at Site 175 contain common to abundant spores and pollen. Cores 1 and 2 contain few palynomorphs and Cores 13 through 22 are barren. The dominance of conifers observed at other sites was also encountered here. Pinus, Tsuga, and Picea are most common, while deciduous trees and grasses are rare. Rare, reworked specimens of Ginkgo, Carya, and Ephedra occur in Core 2. Although data in this hole are sparse, a Tsuga peak occurs which directly corresponds to a rise in diversity and a drop in the pine count (Core 3, Section 4, 38-40 cm). Six meters below this (Core 3, CC) the opposite trend is observed: pine increases to 65 percent of the sample, Tsuga disappears entirely, and diversity drops sharply. It is possible that these extremes at 19.5 and 35 meters represent a warm period followed by a cool period. 
TABLE 2

Palynomorph Occurrence, Holes 174 and 174A

\begin{tabular}{|c|c|c|c|c|c|c|c|c|c|c|c|c|c|c|c|c|c|c|c|c|c|c|c|c|c|c|}
\hline Pollen and Spores & 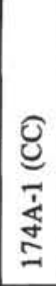 & $\begin{array}{l}\delta \\
\mathcal{C} \\
\tilde{I} \\
\mathfrak{I}\end{array}$ & 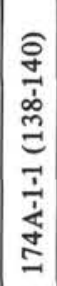 & 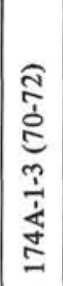 & 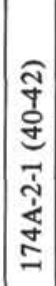 & 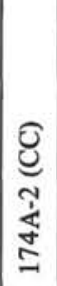 & 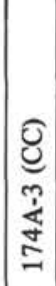 & 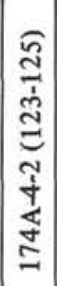 & 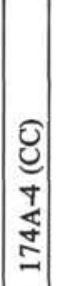 & 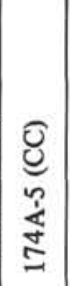 & 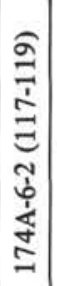 & 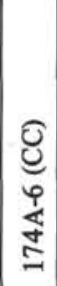 & 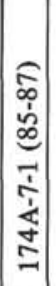 & 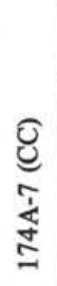 & 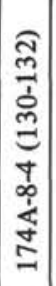 & 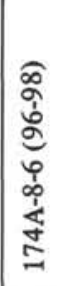 & 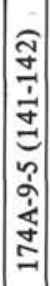 & 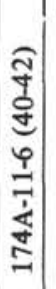 & 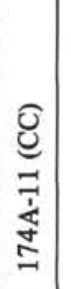 & 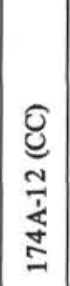 & 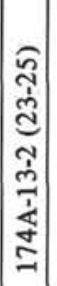 & 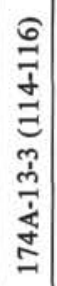 & 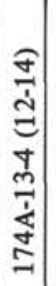 & 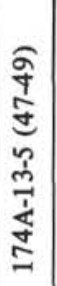 & 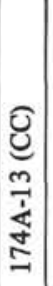 & 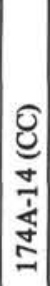 \\
\hline \multicolumn{27}{|l|}{ Trees } \\
\hline Pinus & 162 & 96 & 30 & 33 & & 3 & 2 & 4 & 12 & 101 & 10 & 66 & $30 \mid 1$ & 110 & 2 & 25 & 3 & 14 & 53 & 27 & & 49 & 12 & 9 & 3 & 51 \\
\hline Tsuga & 23 & 14 & 27 & 19 & & & & & & 12 & & 5 & & 8 & & 5 & & 131 & 102 & 4 & 1 & 1 & & 1 & & 17 \\
\hline Picea & 52 & 59 & 22 & 23 & & & 1 & 7 & 9 & 68 & & 31 & 12 & 38 & 1 & 26 & & 5 & 44 & 12 & 1 & 38 & 7 & 16 & 4 & 54 \\
\hline Abies & 5 & 5 & & 2 & & & & & 1 & 3 & & 4 & 1 & & & 4 & & 1 & 3 & 1 & & & & 3 & & 4 \\
\hline Quercus & 12 & 3 & 4 & 3 & & 1 & 1 & & 7 & 22 & & 8 & 17 & 7 & & 8 & & 1 & 3 & 1 & & 2 & & 4 & & 16 \\
\hline Alnus & 38 & 13 & 23 & 8 & & & & & & 2 & 1 & 3 & 1 & 1 & & 4 & & & 2 & 1 & & 3 & & 1 & & 16 \\
\hline Taxodium & 3 & 1 & 7 & 2 & & & & & & & & & & & & & & & & & & & & & & \\
\hline \multicolumn{27}{|l|}{ Fagus } \\
\hline \multicolumn{27}{|l|}{ Cedrus } \\
\hline Acer & 1 & & & & 1 & & & & & & & & & & & 1 & & & & & & & & & & \\
\hline Fraxinus-type & 3 & 2 & & & & & & & & & & & & & & & & & & & & & & & & 1 \\
\hline \multicolumn{27}{|l|}{ Betula } \\
\hline Salix & 2 & 1 & & & & 2 & & & & 4 & & 2 & 5 & 4 & & & 1 & & & 2 & & & & 2 & & 1 \\
\hline Castanopsis & & & & & & & & & & 3 & & & & & & & & & & 1 & & & & 1 & & \\
\hline Ginkgo & & & & & & & & & & & & & & & & & & & & & & & & & & 1 \\
\hline \multicolumn{27}{|l|}{ Carya } \\
\hline Grasses & & & & & & & & & & & & & & & & & & & & & & & & & & \\
\hline Graminae & & 1 & 1 & 2 & & & & & & & & & 1 & 1 & & 4 & & & 1 & & & 1 & & & & 4 \\
\hline Chenopodiaceae & 1 & 1 & & 1 & & & & 1 & & & & & 2 & & & 1 & & & 1 & & & 1 & & & & 2 \\
\hline Compositae & & 1 & & & 1 & & & & & 1 & & 3 & 2 & 1 & & 2 & 1 & & 1 & 2 & 1 & 3 & & & & 3 \\
\hline Ephedra & & & & & & & & & & & & 1 & & & & & & & & & & & & & & \\
\hline Pteridophytes & & & & & & & & & & & & & & & & & & & & & & & & & & \\
\hline Monolete spores & & & 2 & 7 & 1 & 1 & 2 & 1 & & 5 & & 3 & 7 & 3 & & 5 & 1 & 1 & 3 & 2 & & & & 6 & & 9 \\
\hline Trilete spores & & & 3 & 9 & & & & 1 & & 3 & & 2 & 6 & 3 & & 8 & & 1 & 4 & 4 & & & & 3 & & 14 \\
\hline Lycopodiaceae & 1 & 1 & & & 1 & & & & & 2 & & & 4 & 5 & & & & & & & & & & & & \\
\hline Polypodiaceae & 1 & 4 & & 1 & & & & & & & & & 5 & & & & & 1. & 2 & & & & & & & \\
\hline
\end{tabular}

\section{Site $176\left(45^{\circ} 56^{\prime} \mathrm{N}, 124^{\circ} 37^{\prime} \mathrm{W}\right.$; water depth $\left.193 \mathrm{~m}\right)$}

Sediments from Site 176 consist of 41 meters of dark greenish gray clayey silt with a hard fissile shale layer of Pliocene age at the base of the hole. Because Site 176 is located close to the Oregon coast, and the sedimentation rate is low, it was thought that this site would provide a good pollen section. However, palynomorphs occur rarely in these sediments and all pollen found is coniferous. No conclusions concerning climate could be drawn because of low pollen frequencies and diversities.

\section{Site $177\left(50^{\circ} 28^{\prime} \mathrm{N}, 130^{\circ} 12^{\prime} \mathrm{W}\right.$; Water Depth $\left.2006 \mathrm{~m}\right)$}

Lower Pleistocene sand and silt turbidites, with some nannofossil ooze, are the predominant sediments recovered from Site 177, located at the northwestern end of Paul Revere Ridge. Most of the cores examined are barren of spores and pollen. Reasonably well preserved pollen grains (Pinus, Tsuga, Picea) and spores (Lycopodiun), though very rare, occur at the base of Core $5(54 \mathrm{~m})$, whereas, Cores 1 to 4 and 6 to 10 have very fine-grained residues with no plant material.

Abundant, poorly preserved pollen grains occur at the base of Core $13(184 \mathrm{~m})$ along with coaly material (Y. Lancelot, personal communication). The assemblage has a very low diversity and is almost entirely coniferous in nature. Members of the family Polypodiaceae (Polypodium sp. aff. $P$. vulgare type) occur frequently. The occurrence of a badly preserved specimen of the genus Ephedra is the 


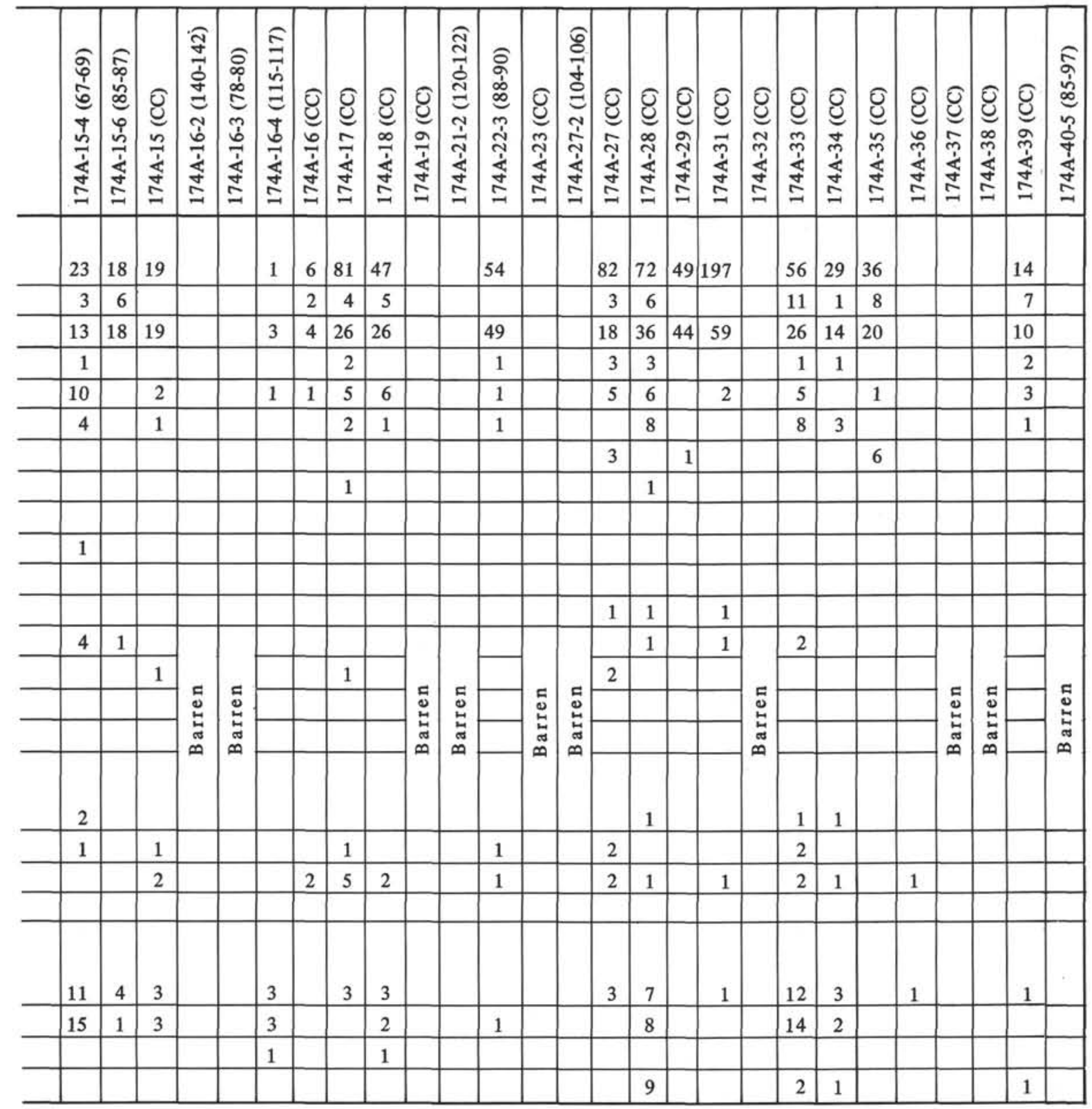

only palynological indicator of Pliocene material in this area; this specimen is possibly reworked.

\section{Site $178\left(56^{\circ} 57^{\prime} \mathrm{N}, 147^{\circ} 47^{\prime} \mathrm{W}\right.$; Water Depth $\left.4218 \mathrm{~m}\right)$}

Sediments at Site 178 consist of gray silty clay with icerafted erratics, diatomaceous sediments, silt and sand turbidites, claystone, and shale.

Samples examined from this site generally contain few or no palynomorphs. Pollen of noteworthy abundance (Cores 24 and 42) is so badly preserved and oxidized that specific identification is impossible. Moreover, identifiable grains (Tsuga, Alnus, Salix, Pinus, psilate and trilete spores) are present in such small quantities that no paleoclimatological determinations could be made.
Coaly fragments are common throughout the cores. Where samples contain abundant diatomaceous material, no palynomorphs or coal fragments were observed. This is most likely the result of dilution by the rapid deposition of organic silica.

\section{Site $179\left(56^{\circ} 24^{\prime} \mathrm{N}, 145^{\circ} 59^{\prime} \mathrm{W}\right.$; Water Depth $\left.3781 \mathrm{~m}\right)$}

Core catcher samples examined at Site 179 were nearly barren of pollen and spores. All specimens found (Pinus and Graminae) showed signs of oxidation. This is probably due, in part, to dilution of the sediment by marine microfossils. 
TABLE 3

Palynomorph Occurrence, Site 175

\begin{tabular}{|c|c|c|c|c|c|c|c|c|c|c|c|}
\hline $\begin{array}{l}\text { Pollen and } \\
\text { Spores }\end{array}$ & 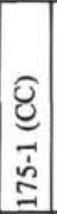 & 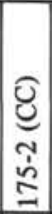 & 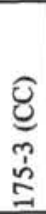 & 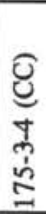 & 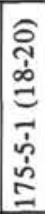 & 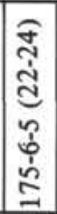 & 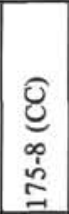 & 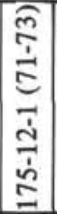 & 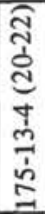 & 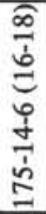 & 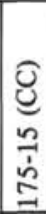 \\
\hline Trees & & & & & & & & & \multirow{23}{*}{ 点 } & \multirow{23}{*}{ 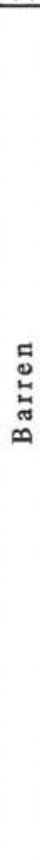 } & \multirow{23}{*}{ : } \\
\hline Pinus & 14 & 32 & 71 & 58 & 38 & 133 & 111 & 24 & & & \\
\hline Tsuga & 4 & & 66 & 1 & 16 & 42 & 26 & 1 & & & \\
\hline Picea & 4 & 5 & 37 & 12 & 17 & 46 & 55 & 6 & & & \\
\hline Abies & & & 3 & 1 & 1 & 8 & 4 & 1 & & & \\
\hline Quercus & 1 & 2 & 1 & 1 & 1 & 1 & 3 & & & & \\
\hline Alnus & & 1 & & & 1 & 9 & 1 & & & & \\
\hline Taxodium & 1 & & 21 & & 5 & 13 & 1 & & & & \\
\hline Betula & & & & & 1 & 1 & 2 & & & & \\
\hline Salix & & & & 2 & 1 & & 1 & & & & \\
\hline Castanopsis & & & & & & 2 & & & & & \\
\hline Ginkgo & & 1 & & & & & & & & & \\
\hline Carya & & 1 & & & & & & & & & \\
\hline Grasses & & & & & & & & & & & \\
\hline Graminae & & & 1 & 1 & & & 1 & & & & \\
\hline Chenopodiaceae & & & 1 & & 2 & & & & & & \\
\hline Compositae & 1 & 4 & 3 & 3 & 2 & 6 & 2 & & & & \\
\hline Ephedra & & 1 & & & & & & & & & \\
\hline Pteridophytes & & & & & & & & & & & \\
\hline Monolete spores & & 2 & 4 & 3 & 4 & & & & & & \\
\hline Trilete spores & & 2 & 2 & 3 & 1 & & & & & & \\
\hline Lycopodiaceae & & & & & & & & & & & \\
\hline Polypodiaceae & & & 7 & 2 & 5 & 1 & & & & & \\
\hline
\end{tabular}

Site $180\left(57^{\circ} 21^{\prime} \mathrm{N}, 147^{\circ} 51^{\prime} \mathrm{W}\right.$; Water Depth $\left.4923 \mathrm{~m}\right)$

Site 180 is located in the eastern Aleutian Trench. Except for occasional, badly oxidized palynomorphs, samples examined at Site 180 are barren of spores and pollen. The scarcity and poor preservation of grains is probably due to a dilution effect resulting from a high sedimentation rate and destruction of pollen grains in sediments of high porosity. Oxidized woody fragments are present throughout the cores. It is also possible that the poor preservation may be the result of increased temperature and pressure.

Site $181\left(57^{\circ} 26^{\prime} \mathrm{N}, 148^{\circ} 27^{\prime} \mathrm{W}\right.$; Water Depth $\left.3086 \mathrm{~m}\right)$

Woody fragments, but no identifiable palynomorphs are present in samples examined at Site 181. Since conditions of deposition at Site 181 were similar to those at Site 180 , lack of well-preserved and abundant spores and pollen was expected.

Site $182\left(57^{\circ} 52^{\prime} \mathrm{N}, 148^{\circ} 42^{\prime} \mathrm{W}\right.$; Water Depth $1411 \mathrm{~m}$ and $1434 \mathrm{~m}$ )

Samples examined at Site 182 were found to be almost barren of spores and pollen. All woody fragments and palynomorphs found were oxidized beyond recognition.

It is interesting to note here that all pollen found at the Gulf of Alaska sites (Sites 178-182) showed signs of extreme oxidation. At Sites 181 and 182 this may be related to high temperatures and pressures which would occur in a zone of subduction. (See Gray and Laplante, this volume).

\section{PALEOCLIMATIC INTERPRETATIONS}

\section{Modern Physiography and Climate of the Related Land} Area

The three sites most relevant to this study are Sites 173, 174 , and 175 (Figure 2). Because of their proximity to each other and to the north Pacific coast, they share a common pollen source area. The pollen found represent a broad spectrum of the northern California-southern Oregon flora but it is necessary to recognize and describe only two major climatic zones, although many microclimates can be found in this area.

The coastal Pacific Northwest has a maritime climate, typified by small year-round temperature variation, fog and cloudiness, a mild winter with abundant rainfall, a relatively cool, dry summer, and a frost-free season of 250 to 300 days (Hansen, 1945). The prevailing winds are southwesterly or northwesterly during most of the year. The coastal area is divided into two major zones: the coastal strip and the coastal range. The coastal strip lies between the coast range and the ocean. Although it is very narrow, it occupies approximately 500 miles of the northern California-southern Oregon coast. The average annual temperature along the strip is about $50^{\circ}$ with an average daily maximum of $57^{\circ}$ and a minimum of $44^{\circ}$. The area is shielded from strong continental influence by mountains of the coast range. These mountains tend to act as barriers and prevent moisture-saturated air from moving inland. Although the annual temperature range in these mountains varies little from the coastal strip, the daily temperature variation is greater. Due to their climatic similarities, both the coastal strip and the coast ranges support a very similar, mainly coniferous flora.

The present-day vegetation of the Oregon coast is dominated by lodgepole pine, Sitka spruce, and western hemlock. Dominant species have probably not changed in this area during the Pleistocene and, although specimens observed at the various sites are not referred to on the specific level, almost all specimens of pine, spruce, and hemlock (Pinus, Picea, and Tsuga) found in DSDP samples fit descriptions for lodgepole pine, Sitka spruce, and western hemlock. Occurring in low proportions are Abies, Alnus, Acer, Graminae, and Compositae (Hansen and Allison, 1942). This vegetation sequence is very similar to the general aspect of pollen diagrams from the sites studied, particularly Sites 173 and 174.

\section{Paleoclimatic Correlation With The Land Section}

Tables 1, 2, and 3 show occurrence of pollen species and number of specimens counted in each sample. As can be seen from these tables and from Figures 3, 4, and 5, gymnosperms, particularly Pinus, Tsuga, and Picea, are dominant at Sites 173, 174, and 175. Deciduous trees, grasses, and Pteridophytes do not occur with great frequency and the most common deciduous trees are Quercus (oak) and Alnus (alder). These pollen profiles are compatible with Hansen's descriptions of late and post-Pleistocene pollen occurrences of continental coastal Oregon, where paleoclimatic change is based on the appearance and abundance of Pinus, Tsuga, and Picea. Climatic optima are characterized by the appearance of alder and grasses. 
POLLEN OCCURRENCE IN EASTERN NORTH PACIFIC SEDIMENTS

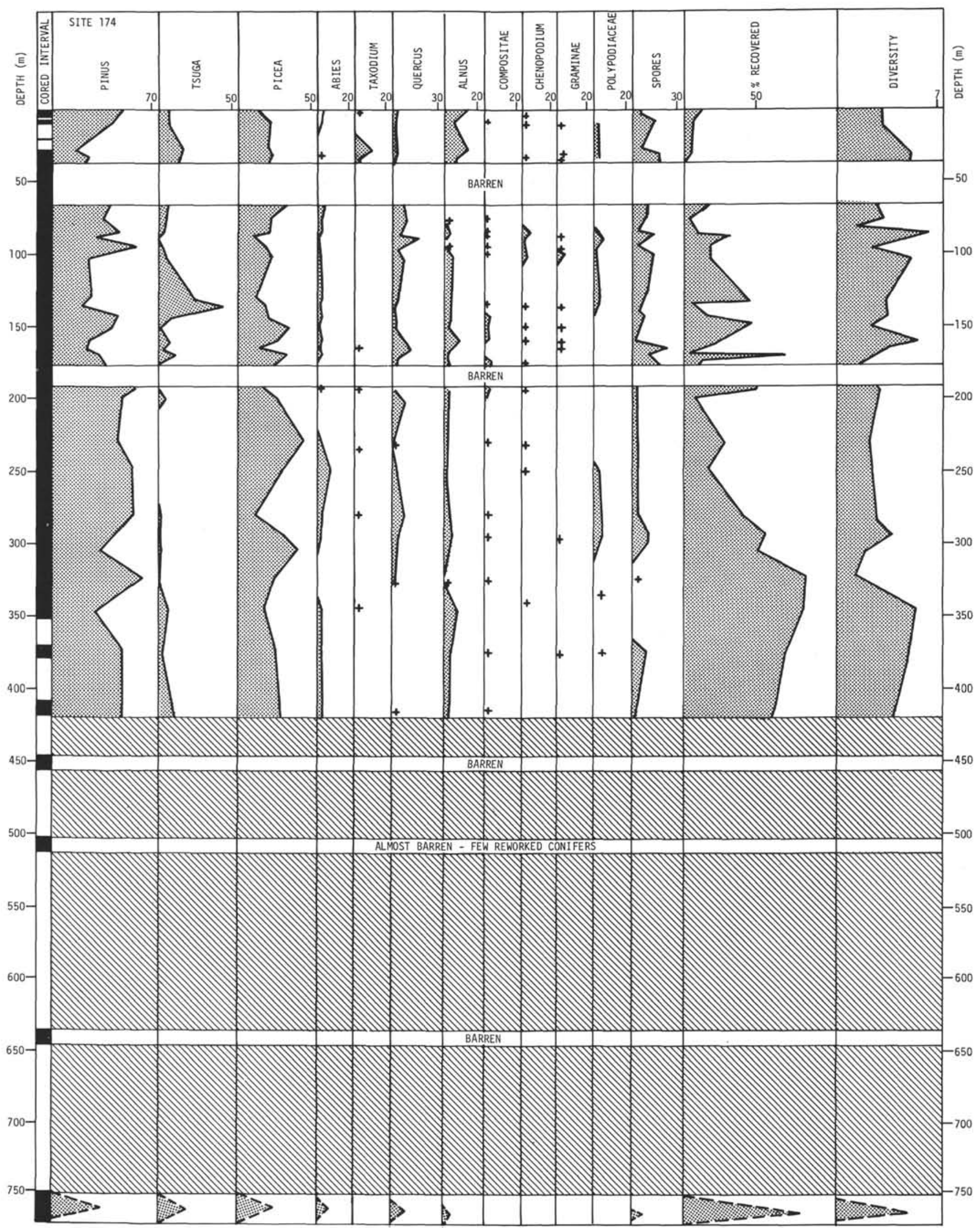

Figure 4. Pollen diagram, Site 174. 


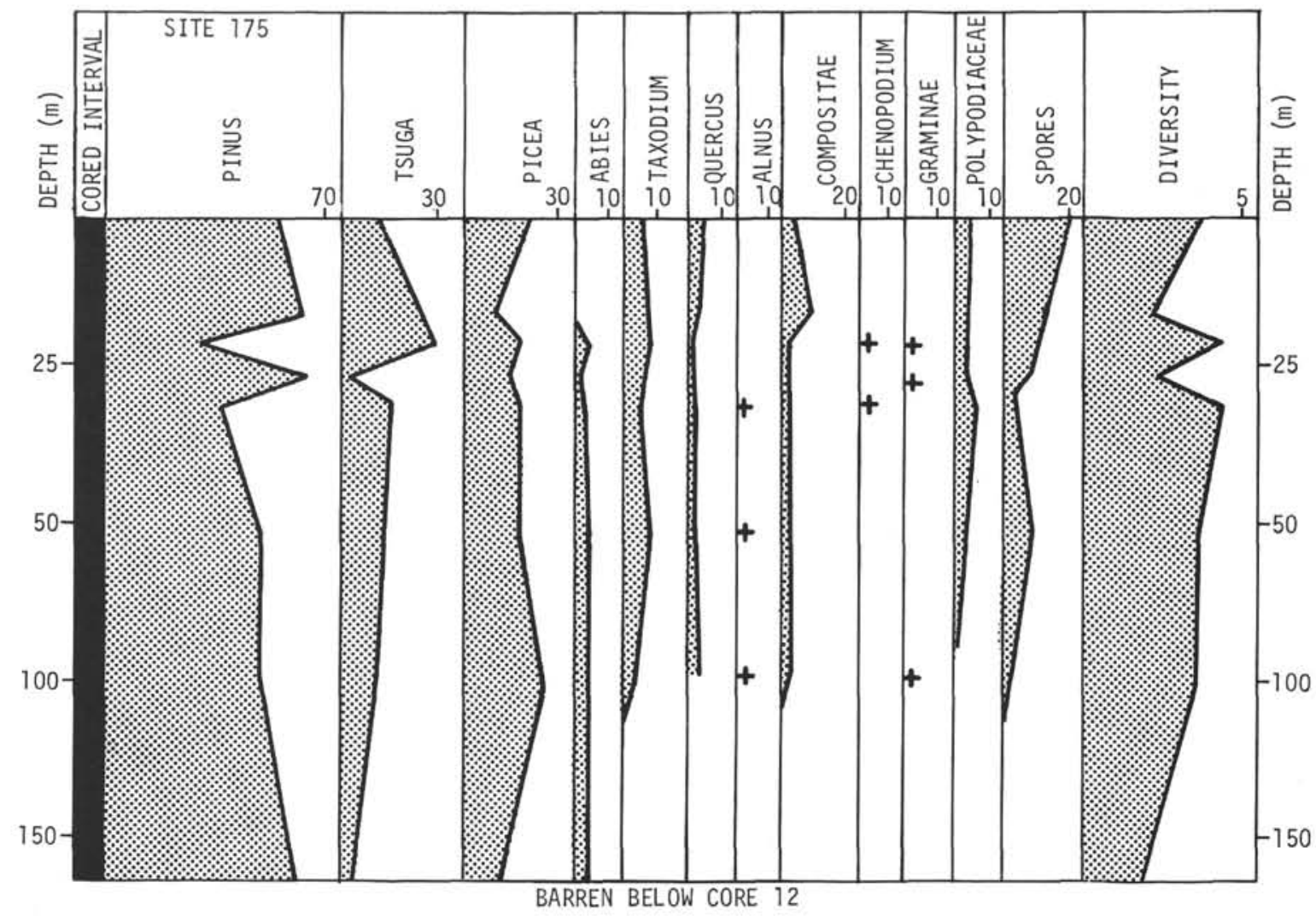

Figure 5. Pollen diagram, Site 175.

At Site 173 there is a marked warming trend at 62 meters, typified by a sudden drop in pine frequency and a sharp rise in diversity.

The fact that Tsuga almost disappears below this point may be the result of Taxodium occupying the ecologic niche in the Pliocene that Tsuga occupies in the mature Pleistocene conifer forest (see Figure 3).

Table 4 shows the location of general climatic trends established by calculating Pinus-Picea-Tsuga ratios and comparing them to diversity. At 224 meters $(24$, CC) there are two samples in an otherwise barren zone which contain genera indicative of a cool period. The age of the samples is middle Miocene.

In order to compare the three major genera at Site 174, a triangle diagram was constructed and normalized values of the three dominant conifers plotted. Samples containing 60 percent or more pine are considered to represent cool periods; samples containing 45 percent or more Tsuga are considered to represent optimal warm; samples dominated by Picea/Pinus are considered to be transitional cool; and those dominated by Picea/Tsuga are transitional warm. The triangular diagram was divided according to these parameters, and samples were plotted with reference to their general location on the diagram. The results are found on Figure 6. The terms cool, transitional cool, transitional warm, and warm are relative and have not been assigned absolute values.

According to these data, the warmest period at Site 174 occurs at 132 meters $(11, \mathrm{CC})$. A transitional warm period occurs at 31 to 34 meters. This may correlate with Hansen's climatic optimum, which occurs on land at $6000-8000$ years B.P. These warm periods correlate with rises in diversity. In general, at Site 174, it should be noted that the diversity curve has excellent inverse correlation with the pine curve, implying that as pine frequency decreases (i.e., the forest matures), diversity increases.

Samples are sparse at Site 175 and therefore climatic interpretation here is quite speculative. One warm transitional period occurs at 24 meters with cool and warm intervals above and below 34 meters. No attempt was made to make paleoclimatic interpretations below this point.

\section{Correlation With Marine Microfossils}

It is possible to draw some climatic correlations between pollen and cooccurring marine microfossils.

Table 4 compares foraminifera and diatom data with that of palynomorphs at Site 173. One obvious correlation is that between diatoms and pollen which occurs at the PlioPleistocene boundary. As shown in the pollen diagram for Site 173 (Figure 2) dramatic reduction of pine frequency cooccurs with a sharp rise in diversity at 72 meters. This correlates with diatom data which show the same warm trend in the Pliocene. Globigerina pachyderma coiling data show an increase of maximum warmth from $12^{\circ} \mathrm{C}$ to $20^{\circ} \mathrm{C}$ below this point.

At 224 meters $(24, \mathrm{CC})$ there appears to be a cool period.

Foram coiling data show a similar upper Miocene cooling period, but at 205 meters.

Table 5 compares pollen data of Site 174 with that of nannofossils and foraminifera. At 31 and 34 meters (where 
TABLE 4

Comparison of Pollen With Cooccurring Marine Microfossils, Site 173

\begin{tabular}{|c|c|c|c|c|c|c|c|c|c|c|c|c|c|}
\hline $\begin{array}{c}\text { Sample } \\
\text { No. }\end{array}$ & $\begin{array}{c}\text { Depth } \\
\text { In Hole } \\
\text { (m) }\end{array}$ & Forams. & Zone & Age & Climate & $\begin{array}{l}\text { Siliceous } \\
\text { Microfossils } \\
\text { (Diatoms) }\end{array}$ & Zone & Age & Climate & $\begin{array}{l}\text { Pollen } \\
\text { Abund. }\end{array}$ & Age & Climate & Sediment Type \\
\hline $1(\mathrm{CC})$ & 5.5 & $\mathrm{~A} / \mathrm{G}$ & \multirow[t]{24}{*}{ N 23} & \multirow{9}{*}{$\begin{array}{l}\text { Late } \\
\text { Pleisto- } \\
\text { cene }\end{array}$} & \multirow{4}{*}{ Cool } & $\mathrm{A} / \mathrm{G}$ & & \multirow{8}{*}{$\begin{array}{l}\text { Pleis- } \\
\text { tocene }\end{array}$} & \multirow{8}{*}{$\begin{array}{l}\text { Warm } \\
\text { - Warm- }\end{array}$} & \multirow{7}{*}{$\begin{array}{l}A / G \\
C / G \\
F / G \\
F / G \\
C / G \\
R / G \\
R / G\end{array}$} & \multirow{7}{*}{$\begin{array}{l}\text { Pleisto- } \\
\text { cene }\end{array}$} & \multirow{7}{*}{ Cool } & Gray green silty clay \\
\hline $2(\mathrm{CC})$ & 15.5 & $\mathrm{~A} / \mathrm{G}$ & & & & $A / G$ & NPD 1 & & & & & & Gray green silty clay \\
\hline $3(\mathrm{CC})$ & 24.5 & $\mathrm{~A} / \mathrm{G}$ & & & & $\mathrm{A} / \mathrm{G}$ & NPD II & & & & & & Gray green silty clay \\
\hline $4(\mathrm{CC})$ & 34.0 & $\mathrm{~A} / \mathrm{G}$ & & & & $\mathrm{A} / \mathrm{G}$ & & & & & & & Gray green silty clay \\
\hline $5(\mathrm{CC})$ & 43.5 & $A / G$ & & & \multirow{20}{*}{ - Cold- } & $\mathrm{A} / \mathrm{G}$ & NPD III & & & & & & Silty clay with some glass \\
\hline $6(\mathrm{CC})$ & 53.0 & $\mathrm{~A} / \mathrm{G}$ & & & & $\mathrm{A} / \mathrm{G}$ & & & & & & & \\
\hline $7(\mathrm{CC})$ & 62.5 & A/G & & & & $\mathrm{A} / \mathrm{G}$ & NPD IV & & & & & & Silty clay with ash \\
\hline $8(C C)$ & 72.0 & $\mathrm{~A} / \mathrm{G}$ & & & & $\mathrm{A} / \mathrm{G}$ & NPD V & & & $\mathrm{A} / \mathrm{G}$ & & & Gray green silty clay \\
\hline $9(\mathrm{CC})$ & 81.5 & $\mathrm{~A} / \mathrm{G}$ & & & & $\mathrm{A} / \mathrm{G}$ & NPD YI & \multirow{5}{*}{$\begin{array}{l}\text { Plio- } \\
\text { cene }\end{array}$} & \multirow{16}{*}{ 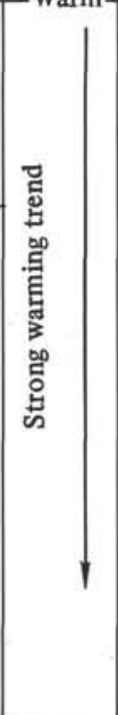 } & $\mathrm{R} / \mathrm{G}$ & & 린 & Gray green silty clay \\
\hline $10(\mathrm{CC})$ & 91.0 & $A / G$ & & \multirow{4}{*}{$\begin{array}{l}\text { Plio- } \\
\text { cene }\end{array}$} & & A/G & 18020 & & & $A / G$ & & & Gray green silty clay \\
\hline $11(\mathrm{CC})$ & 100.5 & $\mathrm{~A} / \mathrm{G}$ & & & & $\mathrm{A} / \mathrm{G}$ & NPD VII & & & $\mathrm{R} / \mathrm{G}$ & Plio- & & Gray green silty clay \\
\hline $12(\mathrm{CC})$ & 110.0 & $\mathrm{~A} / \mathrm{G}$ & & & & $\mathrm{A} / \mathrm{G}$ & 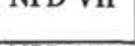 & & & $\mathrm{A} / \mathrm{G}$ & cene & & Gray green silty clay \\
\hline $13(\mathrm{CC})$ & 119.5 & A/G & & & & $\mathrm{A} / \mathrm{G}$ & $\frac{\text { NPD VIII }}{\text { NPD IX }}$ & & & $\mathrm{R} / \mathrm{M}$ & & & Diatom rich silty clay \\
\hline $16(C C)$ & 148.0 & $\mathrm{~A} / \mathrm{G}$ & & Upper & & $\mathrm{A} / \mathrm{G}$ & NPD X & \multirow{11}{*}{$\begin{array}{l}\text { Mio- } \\
\text { cene }\end{array}$} & & $F / G$ & & & Olive gray diatomite \\
\hline $17(\mathrm{CC})$ & 157.5 & $\mathrm{~A} / \mathrm{G}$ & & Miocene & & $\mathrm{A} / \mathrm{G}$ & $\frac{\text { NPD XI }}{\text { NPD XII }}$ & & & $\mathrm{C} / \mathrm{G}$ & & & Olive gray diatomite \\
\hline $18(C C)$ & 167.0 & $\mathrm{~A} / \mathrm{G}$ & & \multirow{9}{*}{$\begin{array}{l}\text { Middle } \\
\text { Miocene }\end{array}$} & & $\mathrm{A} / \mathrm{G}$ & NPD XIII & & & B & & & Nanno rich diatomite \\
\hline $22(\mathrm{CC})$ & 205.0 & $\mathrm{~A} / \mathrm{G}$ & & & & $\mathrm{A} / \mathrm{G}$ & & & & B & & & Nanno rich diatomite \\
\hline $23(C C)$ & 214.5 & $\mathrm{~A} / \mathrm{G}$ & & & & $\mathrm{A} / \mathrm{G}$ & & & & B & & & Nanno rich diatomite \\
\hline $24(\mathrm{CC})$ & 224.0 & $A / G$ & & & & $\mathrm{~A} / \mathrm{G}$ & & & & $\mathrm{F} / \mathrm{G}$ & & & Nanno rich diatomite \\
\hline $25(\mathrm{CC})$ & 233.5 & $\mathrm{~A} / \mathrm{G}$ & & & & $\mathrm{A} / \mathrm{G}$ & & & & $\mathrm{A} / \mathrm{P}$ & & & Nanno rich diatomite \\
\hline $26(C C)$ & 243.0 & $\mathrm{~A} / \mathrm{G}$ & & & & $\mathrm{A} / \mathrm{G}$ & & & & $\mathrm{R} / \mathrm{P}$ & & & Nanno rich diatomite \\
\hline $27(\mathrm{CC})$ & 252.5 & $\mathrm{~A} / \mathrm{G}$ & & & & $\mathrm{A} / \mathrm{G}$ & & & & $\mathrm{R} / \mathrm{P}$ & & & Nanno rich diatomite \\
\hline $29(C C)$ & 271.5 & $\mathrm{~A} / \mathrm{G}$ & & & & $\mathrm{A} / \mathrm{G}$ & & & & $\mathrm{R} / \mathrm{P}$ & & & Diatomite \\
\hline $30(\mathrm{CC})$ & 281.0 & $\mathrm{~A} / \mathrm{G}$ & & & & $\mathrm{A} / \mathrm{G}$ & & & & $\mathrm{R} / \mathrm{P}$ & & & Diatomite \\
\hline
\end{tabular}

${ }^{\text {a }}$ Pollen boundary based on the sudden increase in diversity and decrease in Pinus

pollen abundance and preservation are good) there is a climatic optimum. Pine frequency falls to 15 percent and percentages of Tsuga and Alnus rise to 20 and 15 percent respectively. There is also a sharp rise in diversity. Hansen (1945) found, in his study of post-glacial vegetation on land, a maximum warmth and dryness 8000 to 4000 years B.P., followed by a cooler moister climate which persists to the present day. An age of 8000 years is feasible for this part of the section, considering sedimentation rates for this interval (von Huene and Kulm, this volume).

The next major climatic event occurs at 132 meters, where Tsuga frequency reaches a high of 45 percent and pine drops to 25 percent. This warm period cooccurs precisely with warm-water foraminiferal and nannoplankton species. Also, according to von Huene and Kulm (Chapter 33, this volume, Figure 8) the occurrence of ice-rafted debris in the Gulf of Alaska suggests the beginning of an interglacial just prior to $0.3 \mathrm{~m} . \mathrm{y}$. The sedimentation rate of 132 meters at Site 174 implies a date of approximately 0.3 m.y. for this depth.

Another possible warm trend begins at approximately 270 meters, signified by the reappearance of Tsuga and Alnus. This also marks the beginning of a sharp increase of reworked specimens in this region and coincides with a change in lithology from turbidite to non-turbidite sequences. It is possible that this indicates a change of sediment source (i.e., increased or decreased competency of the Columbia River) rather than climatic change.

Only one marked warm period is observed at Site 175 . This occurs at 24 meters $(175-4, \mathrm{CC})$ and is signified by a decrease in Pinus, an increase in Tsuga, and an increase in diversity. This is neither substantiated nor negated by cooccurring marine microfossils. Due to sparse sampling at Site 175 and lack of pollen below 34 meters, no attempts were made at correlation or interpretation.

\section{CONCLUSIONS}

1. Criteria most meaningful in determining paleoclimates in oceanic sediments off northern California and southern Oregon in the Pleistocene are ratios of Pinus-Picea-Tsuga and the amount of genetic diversity.

2. At no time during the Pleistocene was the coastal area near Sites 172,173 , and 174 ever completely denuded of vegetation. Rather, when climates deteriorated as a result of growth of the glacial ice cap north of the area studied (see Figure 1), pine, the hardiest of the conifers, able to 
TABLE 5A

Comparison of Pollen With Cooccurring Marine Microfossils, Holes 174 and 174A

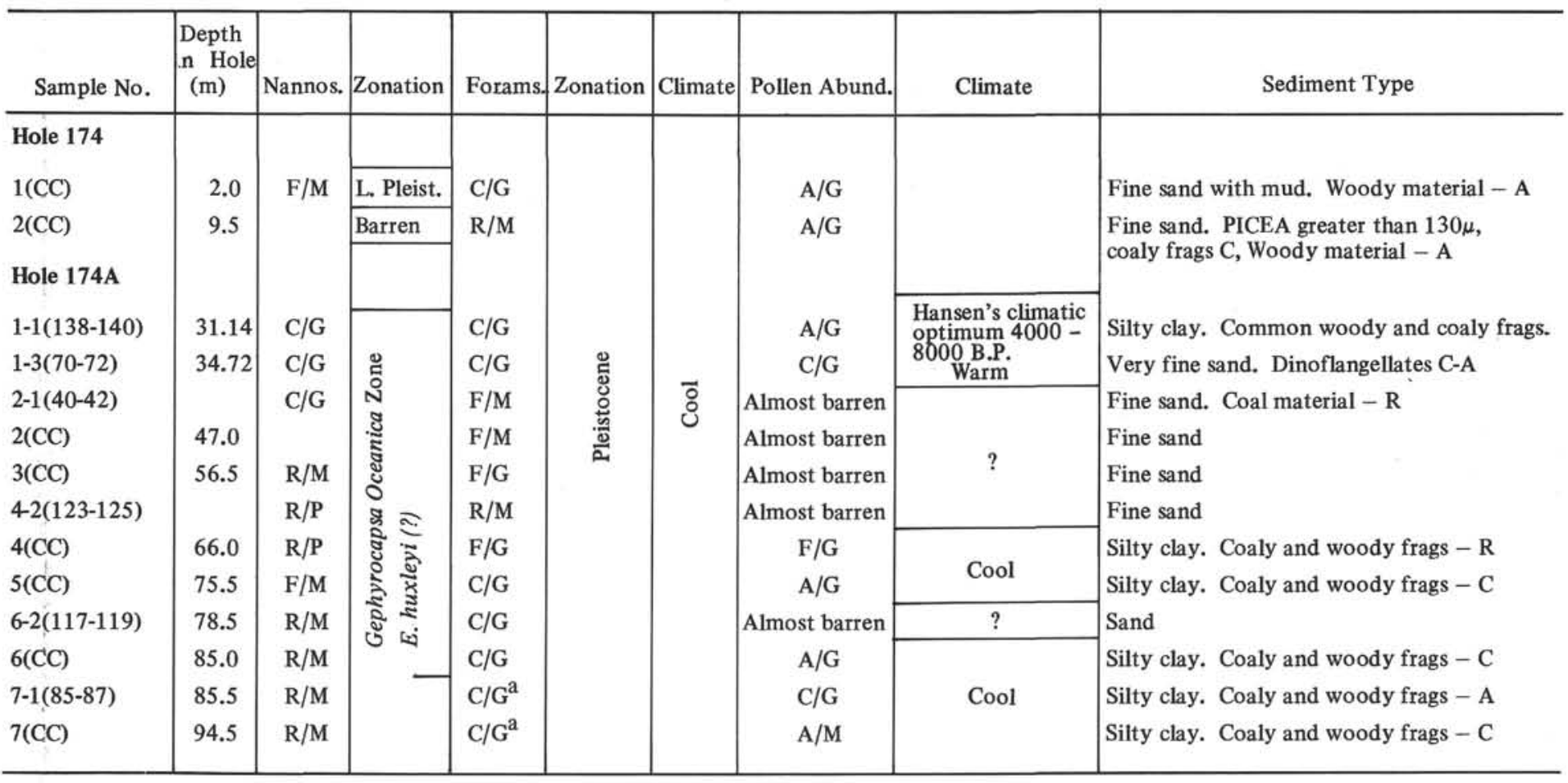

${ }^{\mathrm{a}}$ Near shore.

TABLE 5B

Comparison of Pollen With Cooccurring Marine Microfossils, Hole 174A

\begin{tabular}{|c|c|c|c|c|c|c|c|c|c|}
\hline Sample No. & $\begin{array}{c}\text { Depth } \\
\text { In Hole } \\
\text { (m) }\end{array}$ & Nannos. & Zonation & Forams. & Zonation & Climate & Pollen Abund. & Climate & Sediment Type \\
\hline $8-4(130-132)$ & 98.5 & $\mathrm{R} / \mathrm{M}$ & \multirow{17}{*}{ 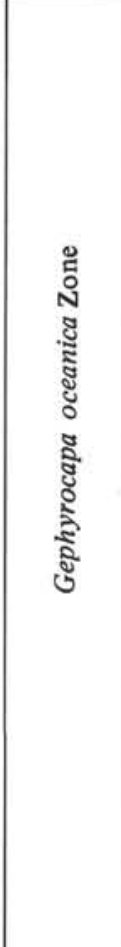 } & $\mathrm{R} / \mathrm{P}$ & \multirow{17}{*}{ 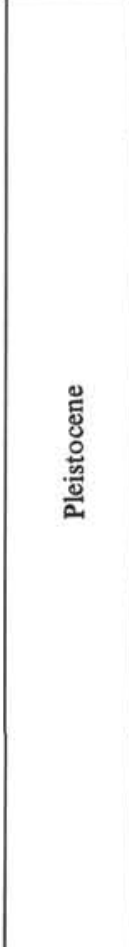 } & \multirow{3}{*}{ Cool } & \multirow{4}{*}{\begin{tabular}{|c|} 
Almost barren \\
C/G \\
\cline { 2 - 3 } Almost barren \\
\cline { 2 - 2 } F/M \\
A/G
\end{tabular}} & $?$ & \multirow{17}{*}{$\begin{array}{l}\text { Sand } \\
\text { Sand } \\
\text { Sand. Coaly frags - C } \\
\text { Silty clay } \\
\text { Fissile mud. Abundant woody and coaly frags. } \\
\text { Fissile mud. Abundant woody material } \\
\text { Silty clay. Woody material - R } \\
\text { Silty clay. Much woody material } \\
\text { Sand } \\
\text { Silty clay. Much woody material } \\
\text { Sand } \\
\text { Fine sand. Much woody and coaly material } \\
\text { Silty clay. Woody material, coaly frags - C } \\
\text { Silty clay. Woody material, coaly frags - C } \\
\text { Sand. Woody material, coaly frags - A } \\
\text { Fine sand } \\
\text { Silty clay } \\
\text { Silty clay. Woody material, coaly frags - C }\end{array}$} \\
\hline $8-6(96-98)$ & 102.5 & $\mathrm{R} / \mathrm{M}$ & & $\mathrm{R} / \mathrm{P}$ & & & & $C_{0}$ & \\
\hline $9-5(141-142)$ & 111.5 & $\mathrm{R} / \mathrm{M}$ & & $\mathrm{F} / \mathrm{M}$ & & & & Cool & \\
\hline $11-6(40-42)$ & 132.0 & $\mathrm{~F} / \mathrm{M}$ & & $\mathrm{C} / \mathrm{G}^{\mathrm{a}}$ & & Warm & & Warm & \\
\hline $12(\mathrm{CC})$ & 142.0 & $\mathrm{R} / \mathrm{G}$ & & $\mathrm{C} / \mathrm{G}$ & & \multirow{13}{*}{ Cool } & $\mathrm{F} / \mathrm{G}$ & \multirow{13}{*}{ Cooler } & \\
\hline $13-2(23-25)$ & 145.0 & $\mathrm{R} / \mathrm{M}$ & & $\mathrm{C} / \mathrm{G}$ & & & Almost barren & & \\
\hline $13-3(114-116)$ & 146.5 & $\mathrm{R} / \mathrm{M}$ & & $\mathrm{C} / \mathrm{G}$ & & & $\mathrm{C} / \mathrm{M}$ & & \\
\hline $13-4(12-14)$ & 148.0 & $\mathrm{R} / \mathrm{M}$ & & $\mathrm{C} / \mathrm{G}$ & & & Almost barren & & \\
\hline $13-5(47-79)$ & 148.5 & $\mathrm{R} / \mathrm{M}$ & & $\mathrm{C} / \mathrm{G}$ & & & $\mathrm{F} / \mathrm{M}$ & & \\
\hline $15-6(85-87)$ & 169.0 & $\mathrm{~F} / \mathrm{M}$ & & $\mathrm{C} / \mathrm{G}$ & & & $\mathrm{F} / \mathrm{M}$ & & \\
\hline $15(\mathrm{CC})$ & 170.5 & $\mathrm{~F} / \mathrm{M}$ & & $\mathrm{C} / \mathrm{G}$ & & & $\mathrm{F} / \mathrm{G}$ & & \\
\hline $16-2(140-142)$ & 173.5 & B & & $R / M^{b}$ & & & Barren & & \\
\hline $16-3(78-80)$ & 175.0 & B & & $\mathrm{R} / \mathrm{M}^{\mathrm{b}}$ & & & Barren & & \\
\hline $16-4(115-117)$ & 176.5 & $\mathrm{R} / \mathrm{M}$ & & $\mathrm{F} / \mathrm{M}^{\mathrm{b}}$ & & & Almost barren & & \\
\hline $16(\mathrm{CC})$ & 180.0 & B & & $\mathrm{F} / \mathrm{M}^{\mathrm{b}}$ & & & Almost barren & & \\
\hline $17(\mathrm{CC})$ & 189.5 & B & & $\mathrm{F} / \mathrm{M}$ & & & $\mathrm{A} / \mathrm{M}$ & & \\
\hline $18(\mathrm{CC})$ & 199.0 & $\mathrm{R} / \mathrm{M}$ & & $\mathrm{F} / \mathrm{M}$ & & & $\mathrm{C} / \mathrm{G}$ & & \\
\hline
\end{tabular}

${ }^{\mathrm{a}}$ Warm, near shore species

${ }^{\mathrm{b}}$ Near shore species 
TABLE 5C

Comparison of Pollen With Cooccurring Marine Microfossils, Hole 174A

\begin{tabular}{|c|c|c|c|c|c|c|c|c|c|}
\hline Sample No. & $\begin{array}{c}\text { Depth } \\
\text { In Hole } \\
(\mathrm{m})\end{array}$ & Nannos. & Zonation & Forams. & Zonation & Climate & Pollen Abund. & Climate & Sediment Type \\
\hline $19(\mathrm{CC})$ & 208.5 & B & & $\mathrm{F} / \mathrm{M}$ & \multirow{13}{*}{ 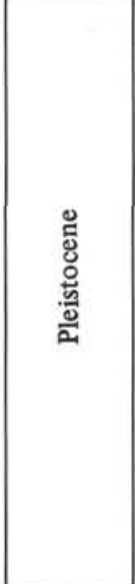 } & \multirow{13}{*}{ Cool } & Barren & \multirow{10}{*}{ Cool } & Sand \\
\hline $21-2(120-122)$ & 221.0 & B & & $\mathrm{R} / \mathrm{M}$ & & & Almost barren & & Sand \\
\hline $22-3(88-90)$ & 230.0 & B & & $\mathrm{R} / \mathrm{P}$ & & & $\mathrm{C} / \mathrm{M}$ & & Silty clay \\
\hline $23(\mathrm{CC})$ & 246.5 & B & & $\mathrm{R} / \mathrm{P}$ & & & & & Silty clay \\
\hline $27-2(104-106)$ & 278.0 & $\mathrm{R} / \mathrm{M}$ & & $\mathrm{C} / \mathrm{G}$ & & & Barren & & Silty clay \\
\hline $27(\mathrm{CC})$ & 284.5 & $\mathrm{R} / \mathrm{M}$ & & $\mathrm{C} / \mathrm{G}$ & & & $\mathrm{A} / \mathrm{M}$ & & Silty clay. Dinoflagellates - C \\
\hline $28(\mathrm{CC})$ & 294.0 & $\mathrm{R} / \mathrm{M}$ & & B & & & $\mathrm{A} / \mathrm{P}$ & & Fissile mud. Coaly and woody frags - A \\
\hline $29(\mathrm{CC})$ & 303.5 & $\mathrm{C} / \mathrm{G}$ & & $\mathrm{F} / \mathrm{M}$ & & & $\mathrm{C} / \mathrm{M}$ & & Silty clay \\
\hline $31(\mathrm{CC})$ & 322.5 & $\mathrm{~F} / \mathrm{M}$ & \multirow{3}{*}{$\begin{array}{l}\text { Cocco- } \\
\text { lithus } \\
\text { doroni- } \\
\text { coides }\end{array}$} & $\mathrm{C} / \mathrm{G}^{\mathrm{a}}$ & & & $\mathrm{A} / \mathrm{P}$ & & Fissile mud. Coaly and woody frags - A \\
\hline $32(\mathrm{CC})$ & 332.0 & $\mathrm{C} / \mathrm{G}$ & & $\mathrm{C} / \mathrm{G}$ & & & Almost barren & & Silty clay. Coaly and woody frags - A \\
\hline $33-2(72-74)$ & 345.0 & $\mathrm{~F} / \mathrm{M}$ & & $\mathrm{R} / \mathrm{M}$ & & & $\mathrm{A} / \mathrm{P}$ & & Fissile mud. Coaly and woody frags - A \\
\hline $34(\mathrm{CC})$ & 379.5 & $\mathrm{~F} / \mathrm{M}$ & & $\dot{\mathrm{s}} \mathrm{C} / \mathrm{G}^{\mathrm{b}}$ & & & $\mathrm{F} / \mathrm{P}$ & & Fissile mud. Coaly and woody frags - C \\
\hline $35(\mathrm{CC})$ & 417.5 & $\mathrm{~F} / \mathrm{M}$ & E.annula & $\stackrel{\mathrm{a}}{\mathrm{A}} / \mathrm{G}^{\mathrm{b}}$ & & & $\mathrm{C} / \mathrm{P}$ & & Fissile mud \\
\hline $36(\mathrm{CC})$ & 455.0 & $\mathrm{R} / \mathrm{M}$ & & $\mathrm{C} / \mathrm{G}^{\mathrm{b}}$ & & & Barren & Warmer & Fissile mud. Coaly and woody frags - C \\
\hline $37(\mathrm{CC})$ & 512.5 & B & & g $\mathrm{F} / \mathrm{M}^{\mathrm{b}}$ & Pliocene & & Barren & & Fissile mud \\
\hline $38(\mathrm{CC})$ & 645.0 & $\mathrm{R} / \mathrm{M}$ & & E. $R / \mathrm{P}^{\mathrm{b}}$ & forms & Warm & Barren & & Silty clay. Coaly and woody frags - C \\
\hline $39(\mathrm{CC})$ & 759.5 & $\mathrm{R} / \mathrm{M}$ & & $\mathrm{C} / \mathrm{M}^{\mathrm{b}}$ & & & $\mathrm{F} / \mathrm{P}$ & & Limestone and sandstones. Coaly and woody frags - C \\
\hline $40-5(85-87)$ & 778.5 & B & & $\mathrm{F} / \mathrm{M}$ & & & Barren & & Calcareous mudstone \\
\hline
\end{tabular}

${ }^{a}$ Near shore

${ }^{b}$ Warm trend

TABLE 6

Comparison of Pollen With Cooccurring Marine Microfossils, Site 175

\begin{tabular}{|c|c|c|c|c|c|c|c|c|c|c|c|c|}
\hline Sample No. & $\begin{array}{c}\text { Depth } \\
\text { In Hole } \\
\text { (m) }\end{array}$ & Nannos. & Zonation & Climate & Forams. & Zonation & Climate & $\begin{array}{c}\text { Diatoms } \\
\text { Zonation }\end{array}$ & Climate & $\begin{array}{l}\text { Pollen } \\
\text { Abund. }\end{array}$ & Climate & Sediment Type \\
\hline \multirow{7}{*}{$\begin{array}{l}1(C C) \\
2(C C) \\
3-4(38-40) \\
3(C C) \\
5-1(18-20) \\
6-5(22-24) \\
8(C C) \\
12-1(71-73)\end{array}$} & \multirow{7}{*}{$\begin{array}{r}5.0 \\
14.5 \\
19.5 \\
24.0 \\
34.0 \\
49.2 \\
71.5 \\
100.5\end{array}$} & \multirow{7}{*}{$\begin{array}{l}F / P \\
F / P \\
F / M \\
B \\
F / M \\
B \\
F / M \\
A / G\end{array}$} & \multirow{7}{*}{ 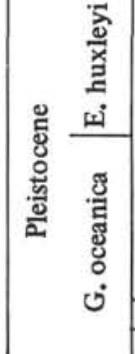 } & & \multirow{7}{*}{$\begin{array}{l}\mathrm{C} / \mathrm{M} \\
\mathrm{C} / \mathrm{G} \\
\mathrm{C} / \mathrm{G} \\
\mathrm{C} / \mathrm{G} \\
\mathrm{C} / \mathrm{M} \\
\mathrm{F} / \mathrm{M} \\
\mathrm{C} / \mathrm{G} \\
\mathrm{A} / \mathrm{G}\end{array}$} & \multirow{7}{*}{$\begin{array}{l}\text { Late } \\
\text { Pleisto- } \\
\text { cene }\end{array}$} & & \multirow{7}{*}{$\begin{array}{l}\mathrm{A} / \mathrm{G} \\
\mathrm{A} / \mathrm{G} \\
\mathrm{C} / \mathrm{M} \\
\mathrm{C} / \mathrm{M} \\
\mathrm{F} / \mathrm{M} \\
\mathrm{C} / \mathrm{M} \\
\mathrm{C} / \mathrm{M}\end{array}$} & \multirow{7}{*}{\multicolumn{2}{|c|}{$\begin{array}{l}\text { F/G } \\
\text { F/G } \\
\text { A/M } \\
\text { C/G } \\
\text { C/M } \\
\text { A/M } \\
\text { A/M } \\
\text { R/P }\end{array}$}} & \multirow{2}{*}{ Cool } & \multirow{7}{*}{$\begin{array}{l}\text { Diatom bearing silty clay } \\
\text { Silty clay } \\
\text { Silty clay } \\
\text { Silty clay } \\
\text { Silty clay } \\
\text { Silty clay } \\
\text { Silty clay } \\
\text { Silty clay } .26 \mathrm{~m} . \mathrm{y} . \\
.30 \mathrm{~m} . \mathrm{y} .\end{array}$} \\
\hline & & & & & & & & & & & & \\
\hline & & & & & & & & & & & Trans. & \\
\hline & & & & & & & & & & & Warm & \\
\hline & & & & & & & & & & & & \\
\hline & & & & & & & & & & & ? & \\
\hline & & & & mamil & & & waim & & & & & \\
\hline
\end{tabular}

tolerate strong winds and unstable soil conditions, dominated. It is also probable that during glacial periods in this area, the change in climate was not only a cooling in temperature, but initiation of year-round precipitation rather than the seasonal precipitation now found.
3. It is possible to correlate changes in oceanic temperature with that of land, provided that the climatic change is a large-scale one.

4. The use of reworked pollen to determine glacialinterglacial boundaries does not seem indicative of climatic 


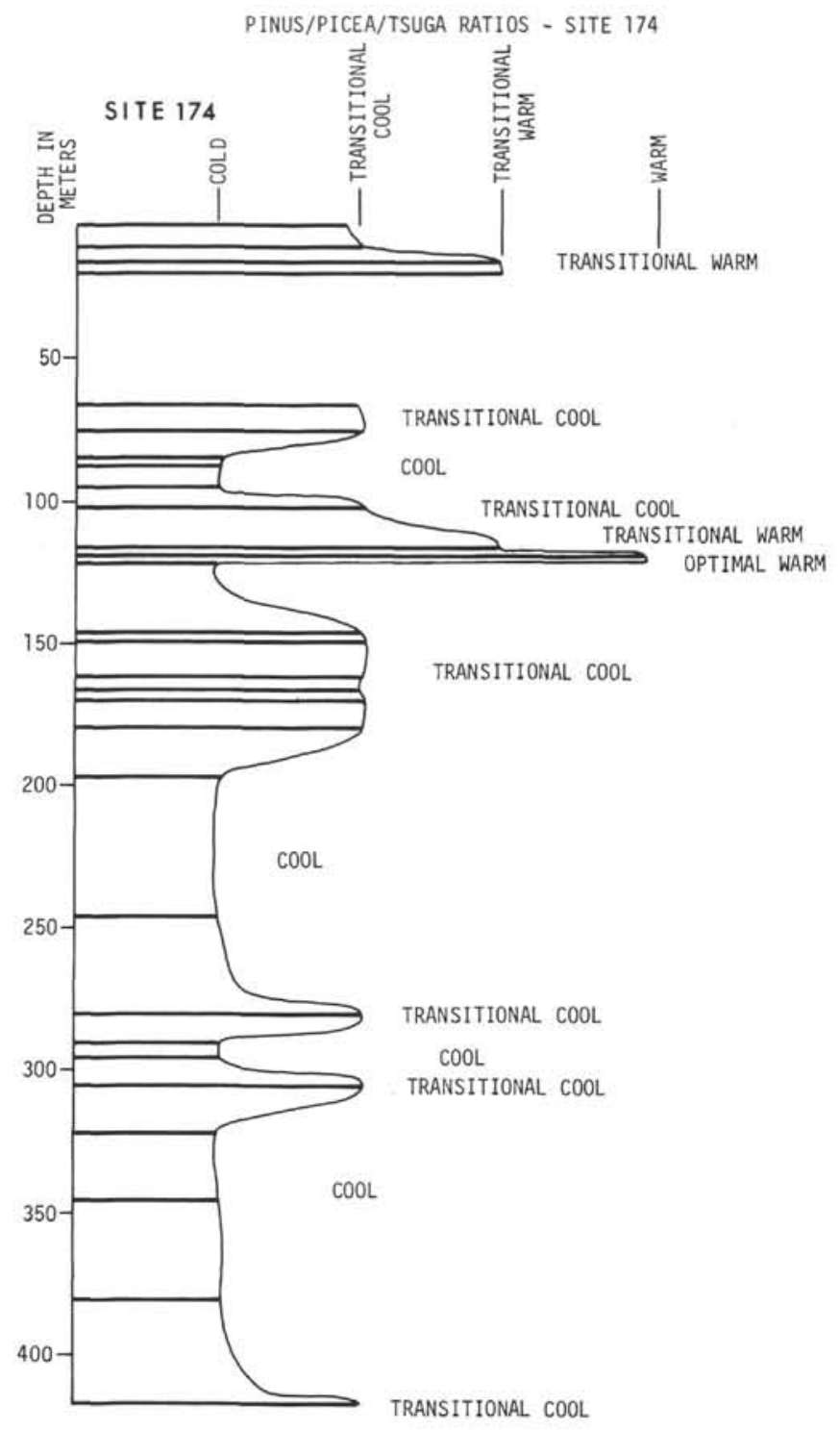

Figure 6. Pinus/Picea/Tsuga Ratio, Site 174. changes in the coastal areas of northern California and southern Oregon.

\section{REFERENCES}

Brown, C. A., 1960. Palynological Techniques. Unpublished manuscript, p. 28

Erdtman, G., 1943. An Introduction to Pollen Analysis. The Ronald Press Company. 239 p.

Fischer, A. G., 1960. Latitudinal variations in organic diversity. Evolution. 14 (1), 64.

Hansen, H. P., 1938. Pollen analysis of three bogs on Vancouver Island, Canada. Trans. Am. Phil. Soc. , 1941. Paleoecology of two peat deposits on the Oregon Coast. Oregon State Univ. Monographs, Studies in Botany, 3. , 1945. Post-glacial vegetation of Eastern Washington. Northwest Science. 18 (4), 79. , 1947. Post-glacial forest successions: Climate and chronology in the Pacific Northwest. Monograph.

Hansen, H. P. and Allison, I. S., 1942. A pollen study of a fossil peat deposit on the Oregon Coast. Northwest Science. $16,86$.

Koreneva, E. V., 1964. Distribution of spores and pollen of terrestrial plants in bottom sediments of the Pacific Ocean. In Ancient Pacific Floras. Univ. Hawaii Press. 31.

Leopold, E. B., 1969. Late Cenozoic Palynology. In Tschudy, R. H. and Scott, R. A. Aspects of Palynology. New York. 377.

Norem, W. L., 1956. Tertiary spores and pollen related to paleoclimates and stratigraphy of California. Micropaleontology. 2 (4), 313.

Stanley, C.A., 1965. Use of reworked pollen and spores for determining the Pleistocene-Recent and the intra-Pleistocene boundaries. Nature. 206 (4981), 289.

Staplin, F., 1969. Sedimentary organic matter, organic metamorphism, and oil and gas occurrence. Canadian Petrol Geol. 17 (1), 47. 
PLATE 1
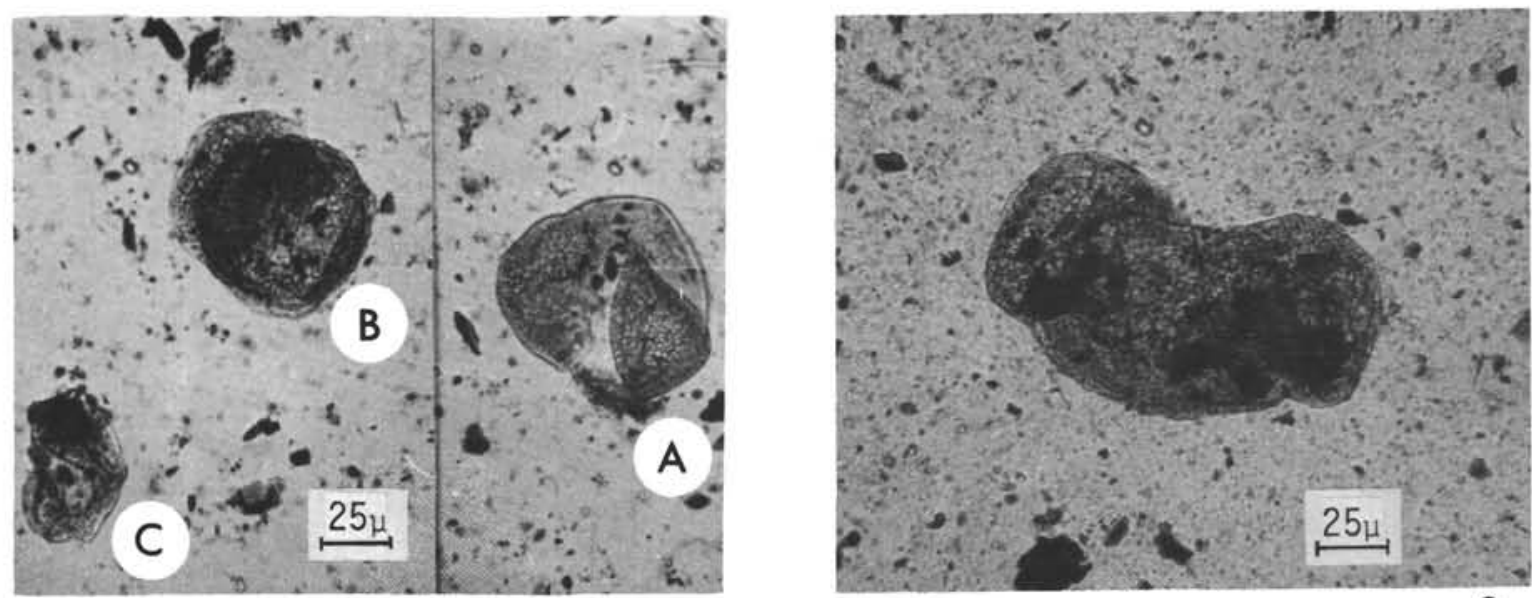

1
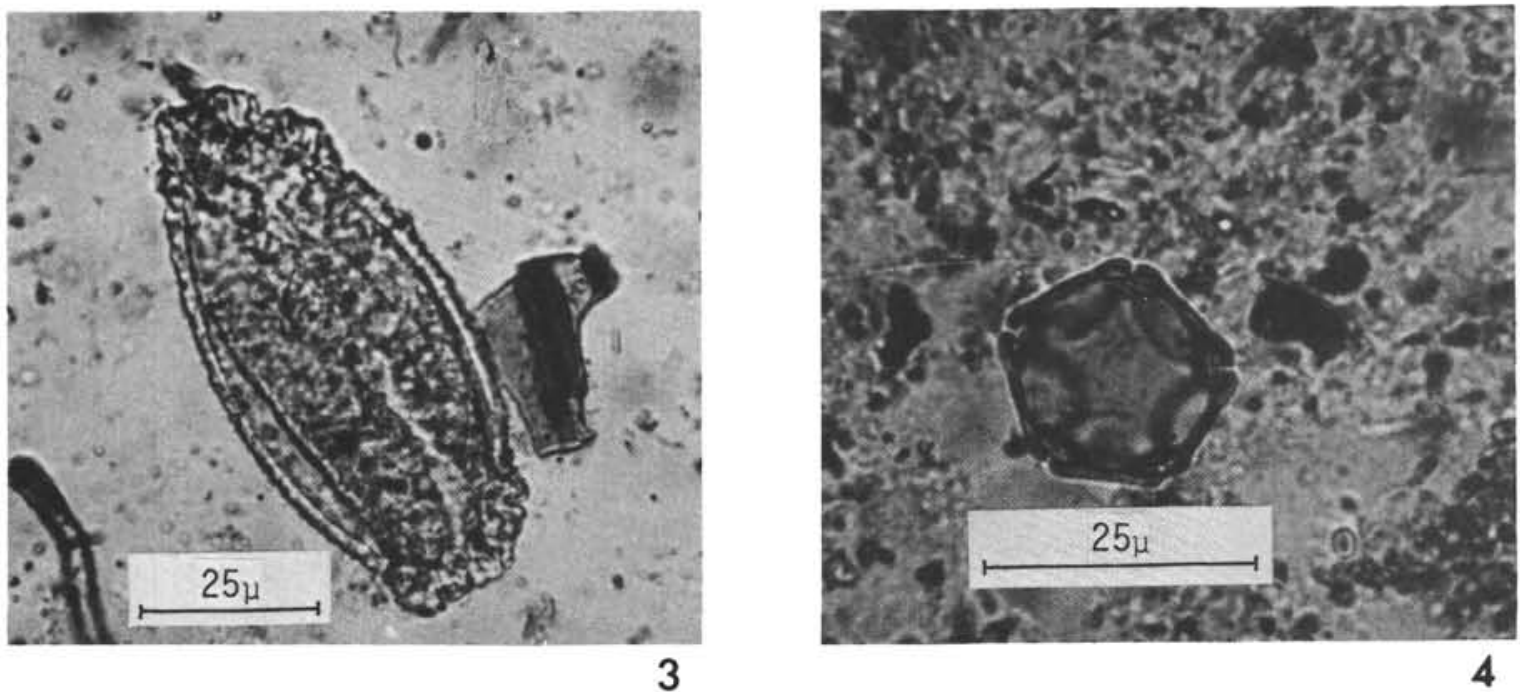

Figure 1. Picea and pine grains showing three states of preservation in the same core $(173-8, \mathrm{CC})$.

Figure 2. Highly oxidized Picea grain from the bottom of Hole 174A.

Figure 3. Tsuga $(750 \mathrm{X})$.

Figure 4. Alnus (1250 X). 


\section{Plate 2}
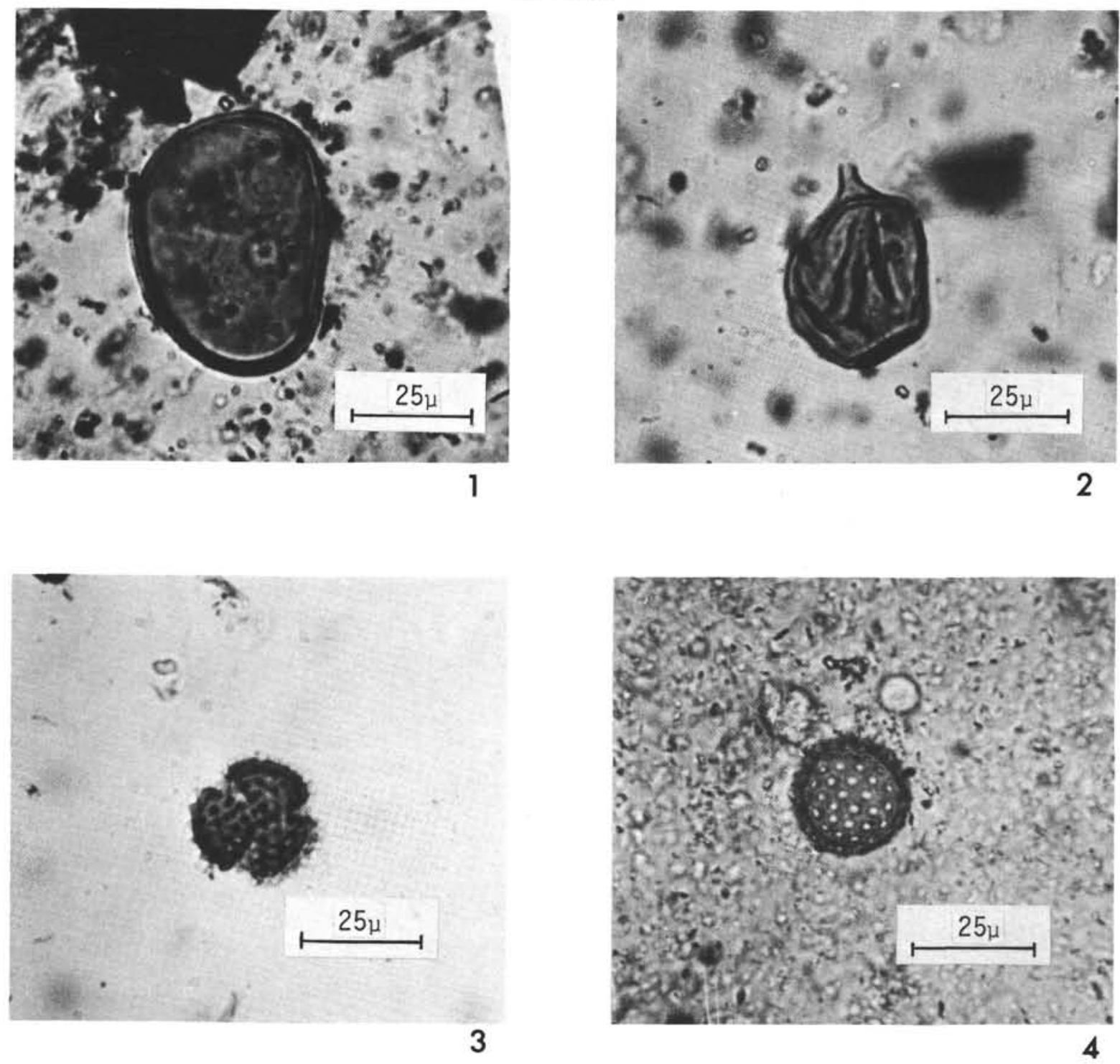

Figure 1. Graminae (750 X).

Figure 2. Taxodium type (1250 X).

Figure 3. Artemesia (750 X).

Figure 4. Chenopodium (750 X). 


\section{PLATE 3}
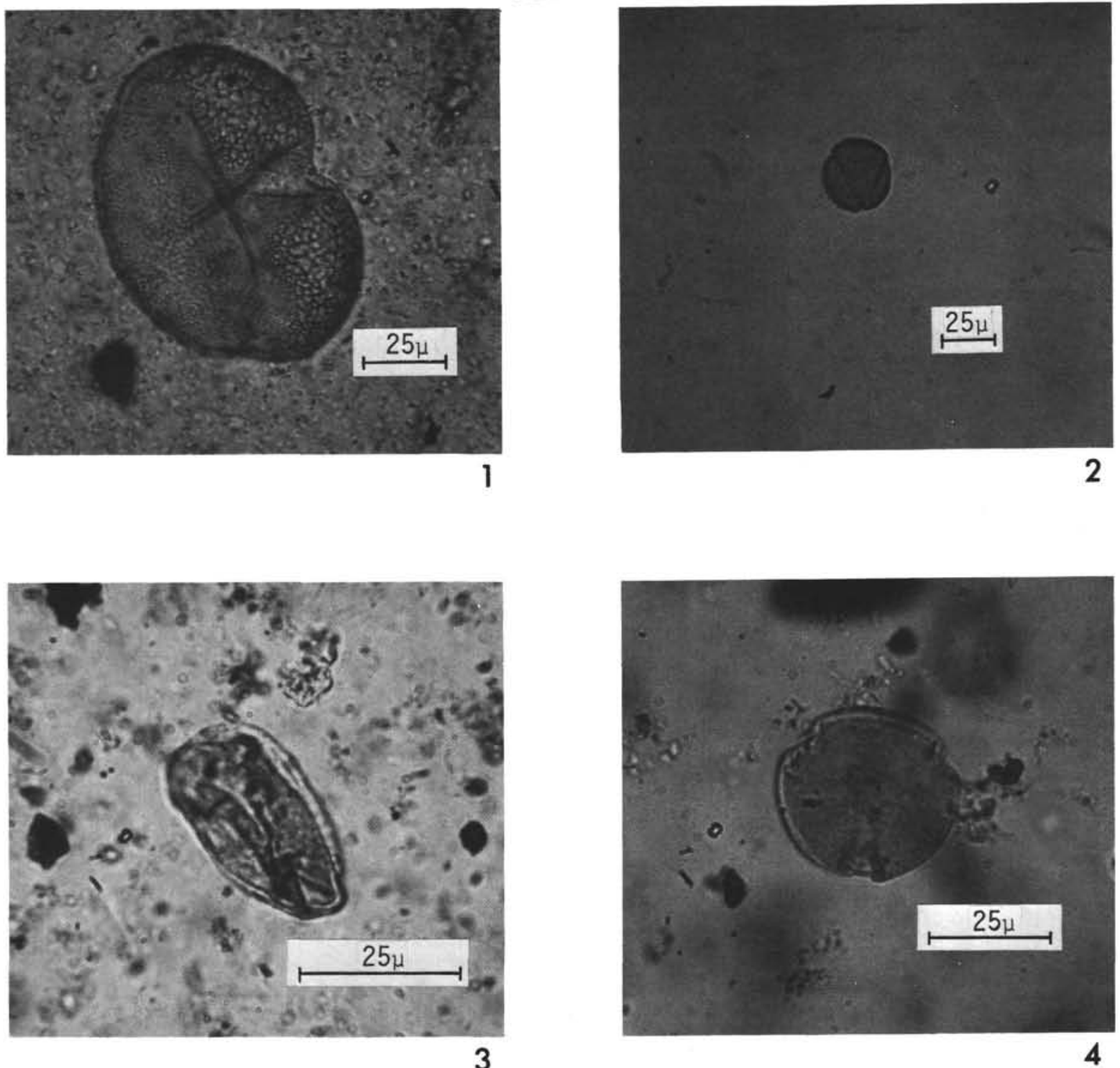

Figure 1. Picea (300 X).

Figure 2. Quercus (750 X).

Figure 3. Ginkgo (?) from 175-6-5 (22-24) (1250 X).

Figure 4. Nyssa from 174A-28 (CC) (750 X). 